\title{
THE ANCIENT CITY OF OSOR, NORTHERN ADRIATIC, IN INTEGRATED ARCHAEOLOGICAL PROSPECTION
}

\section{NIVES DONEUS, MICHAEL DONEUS, ZRINKA ETTINGER-STARČIĆ}

UDC: 902.2(497.572Osor)

Preliminary communication

Manuscript received: 01. 03. 2017.

Revised manuscript accepted: 14. 03. 2017.

DOI: 10.1484/J.HAM.5.113761
N. Doneus*

Vienna, Austria

M. Doneus ${ }^{* * * *}$

Vienna, Austria

Z. Ettinger-Starčić***

Mali Lošinj, Croatia

In 2012, the Ludwig Boltzmann Institute for archaeological prospection and virtual archaeology (LBI ArchPro) launched a strategic project with the focus on Mediterranean environments. It seemed to be necessary to test the applicability of various prospection techniques to achieve an integrative approach for documentation and investigation of archaeological sites in this environmental context. Therefore, adequate geographical areas have been selected to be systematically investigated within the project. This paper presents an overview of this research in the area of Osor. First, the case study area is presented, along with its specific archaeological questions. Next, the methodologies used to investigate these questions are detailed. Finally, the results are presented and discussed.

Keywords: Archaeological prospection, airborne laser scanning, geophysical prospection, Osor

\section{INTRODUCTION}

The "digital age" has brought fundamental changes to archaeological methodologies. One of the fields that has specifically benefited from the potential of technical developments is archaeological prospection, which deals with non-destructive identification, documentation and interpretation of archaeological landscapes and their palaeoenvironment. Archaeological prospection comprises a broad range of techniques, the most important of which are remote sensing, geophysical prospection and systematic field walking approaches. All of these have been in use for a long period of time. However, the last decade has specifically enhanced the possibilities of remote sensing and geophysical prospection. As a result, they are currently the prime non-destructive choice to capture invisible archaeological landscapes efficiently and in high-resolution. While archaeological prospection is gaining recognition, it is, like

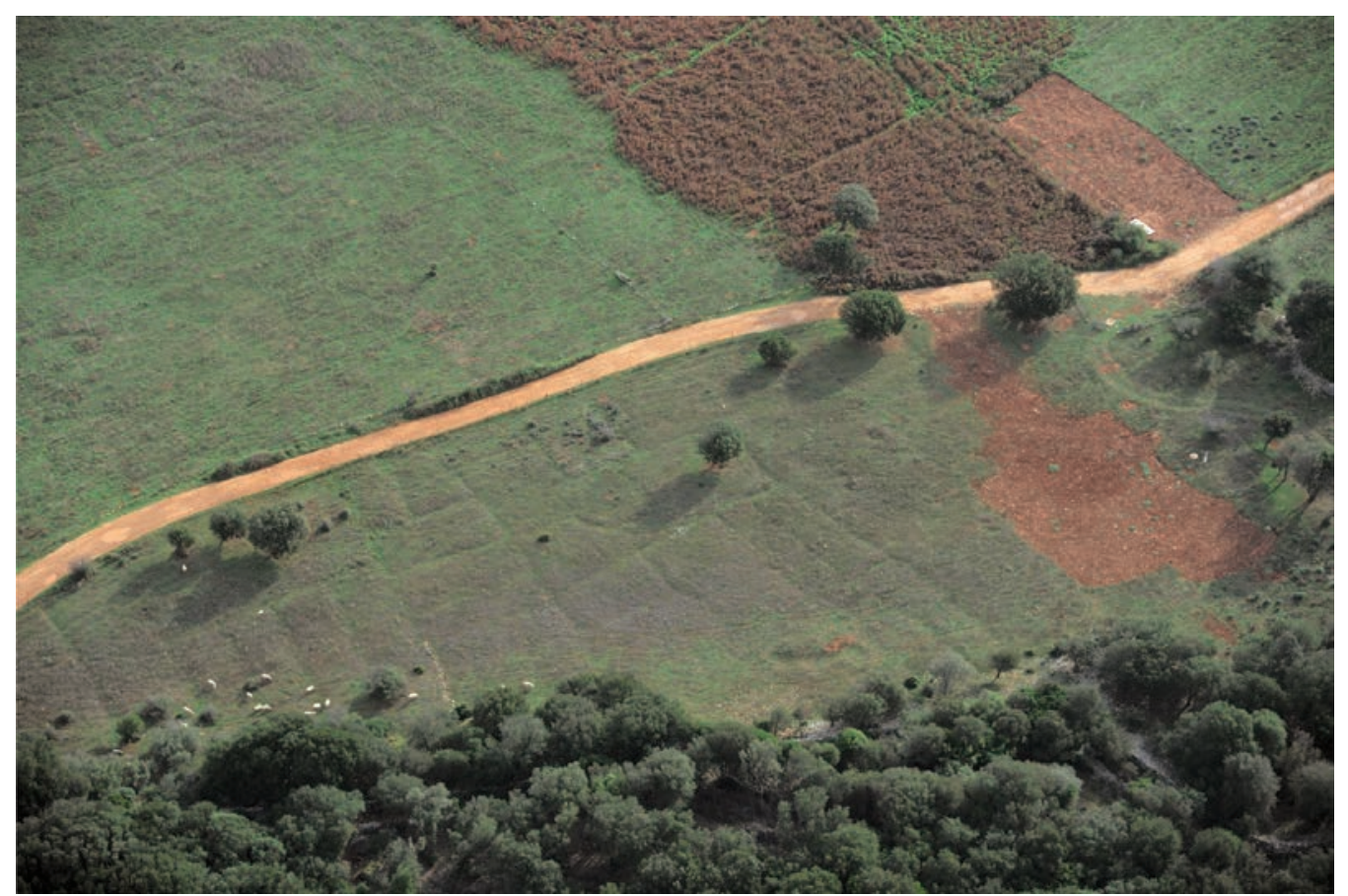

Fig. 1: Aerial photographs from the case study region rarely reveal traces of past landscapes as in the case of fertile plains near the village of Artatore, on the island of Losinj. CMichael Doneus

\footnotetext{
" Ludwig Boltzmann Institute for archaeological prospection and virtual archaeology, Hohe Warte 38, 1190 Vienna, Austria

${ }^{* *}$ Department of Prehistoric and Historical Archaeology, University of Vienna, Franz-Klein-Gasse 1, 1190 Vienna, Austria

*** Lošinj Museum, V. Gortana 35, 51550 Mali Lošinj, Croatia
} 
any other field method in archeology, strongly influenced by landscape characteristics. Geological formations, soil and vegetation, climatic conditions, and the weather during field work will all influence the quality of prospection results.

The application of non-invasive prospection (aerial archaeology, airborne laser scanning and geophysical prospection) seems to be specifically challenging in the karstic Mediterranean landscape. Mediterranean cities in Eastern Adriatic often have a long continuity of occupation. Many of them have been populated for more than 2000 years, which makes archaeological prospection in the urban area desirable but almost impossible due to the density of buildings and the narrow roads. Outside the city areas, dense, low, and mainly evergreen Mediterranean vegetation as well as eroded and accumulated soils make it difficult to prospect archaeological heritage. Extensive and detailed cropmarks of archaeological structures, which are typical for Central and Northern Europe, are usually not present in these environments. Therefore, images from aerial archaeology campaigns mainly record earthworks or relief features such as stone settings of hillforts, barrows, submerged harbour sites etc. (fig. 1). Airborne laser scanning seems to be equally difficult, essentially because of the above mentioned vegetation. Geophysical prospection is impossible in the densely vegetated areas and on stony surfaces, which are eroded by the strong winds, especially on the north-facing side of many islands. While pastures, vineyards and olive plantations can technically be prospected, the application of large-scale geophysical prospection in such areas remains rare. Additionally, the rising sea level hides a good deal of former coastal structures under very shallow water. Due to these difficulties, archaeological research has mainly relied upon field walking and excavation above and undersea. This has resulted in a fragmented picture of single sites, leaving little evidence with which to reconstruct detailed historical landscapes.

Therefore, in 2012, the Ludwig Boltzmann Institute for archaeological prospection and virtual archaeology (LBI ArchPro) launched a strategic project in order to investigate this challenging environment. Its aim was twofold: On the one hand, it seemed to be necessary to test the applicability of various prospection techniques to achieve an integrative approach for documentation and investigation of archaeological sites in this environmental context. On the other hand, specific archaeological questions should be addressed. Therefore, adequate geographical areas have been selected to be systematically investigated within the project. The first application of large-scale prospection was initiated with a test Airborne Laser Scanning flight covering several sample areas of the Cres/Lošinj archipelago. In 2014 and 2015 high-resolution geophysical measurements followed, concentrating on the archaeological site of Osor, located at the isthmus between the northern Adriatic islands Cres and Lošinj. This paper presents an overview of this research. First, the case study area is presented, along with its specific archaeological questions. Next, the methodologies used to investigate these questions are detailed. Finally, the results are presented and discussed.

\section{CASE STUDY AREA}

The Croatian islands of Cres and Lošinj form, together with Krk and Rab, the most northern group of Croatian islands. Geologically, the whole coast of Croatia is part of the mountain chain of the Dinarides. The islands of the Kvarner gulf mainly consist of Cretaceous carbonates and Palaeogene sandstone and carbonates. Tectonically, the islands are part of the External Dinaric Imbricated Belt, which has been deformed mainly in the Eocene and Upper Pliocene; related deformation structures still dominate the landscape of this $\mathrm{area}^{1}$. The northern part of the island of Cres is influenced by the sub-Mediterranean climate; the south parts of Cres as well as the island of Lošinj have characteristics of the Mediterranean climate ${ }^{2}$.

The karstic limestone of the case study area is densely covered with typical Mediterranean vegetation consisting mainly of dense, rigid, mostly evergreen shrubbery (macchia). In some areas, abandoned and recently used olive tree plantations enclosed by dry stone walls can be found. Macchia, which is anthropogenic secondary vegetation, and a system of dry stone walls covering most of the island are indicators of intensive past human utilization.

The modern village of Osor (with its 6o inhabitants3) conceals archaeological traces from several thousand years (fig. 2). As with any settlement, Osor's location and its specific layout is a result of economic, social, political, geographical, and historical factors. As such, Osor is located on a small, almost circular land-bridge between the two islands of Cres and Lošinj, providing suitable conditions for a harbour as well as for protection. The city wall, which has its origin in prehistory ${ }^{4}$, encloses an almost circular area with a diameter of $300 \mathrm{~m}$. In the south, west and north, it is bounded by the sea, while in the north-east and east, the settlement area is limited by a moist depression.

On the western edge of Osor, the city is bounded by a $10 \mathrm{~m}$ wide channel, which also divides the islands Cres and Lošinj. It is a widely accepted theory that the channel is artificial. Based on her excavations from 1972, Aleksandra Faber argued for a construction no later than Roman times, due to the finding of a Roman cesspit which emptied into the channel ${ }^{5}$. The channel is also seen as crucial for seafaring and the location of Osor as a point of significant advantage for control of the sea route between the islands ${ }^{6}$.

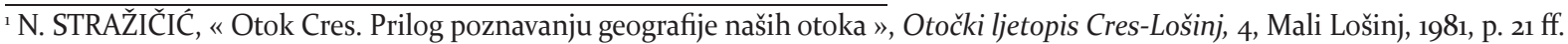

${ }^{2}$ N. STRAŽıČIĆ, « Otok Cres. Prilog poznavanju geografije naših otoka », Otočki ljetopis Cres-Lošinj, 4, Mali Lošinj, 1981, p. 41 f.

${ }_{3}^{3}$ Croatian bureau of statistics. http://www.dzs.hr/

${ }^{4}$ A. MOHOROVIČIĆ, « Analiza razvoja urbanističke strukture naselja na otocima zapadnog Kvarnera », Ljetopis JAZU, 61, Zagreb, 1956, p. 468 ff.

${ }^{5}$ A. FABER, « Počeci urbanizacije na otocima sjevernog Jadrana », Izdanja HAD, 7, Zagreb, 1982, p. 62 and footnote 6.

${ }^{6}$ Already Otto Benndorf was in 1880 convinced that Osor owed his importance to his geographical situation (O. BENNDORF, « Ausgrabungen in Ossero », Archaeologisch-epigraphische Mittheilungen aus Oesterreich, 4, Wien, 188o, p. 74). The same opinion is also given by Andre Mohorovičić since his earliest articles on Osor (A. MOHOROVIČIĆ, « Prilog analizi razvoja historijske arhitekture na otocima Lošinju i Cresu », Ljetopis JAZU, 59, Zagreb, 1954, p. 215 f.) and is still shared in the literature.
} 


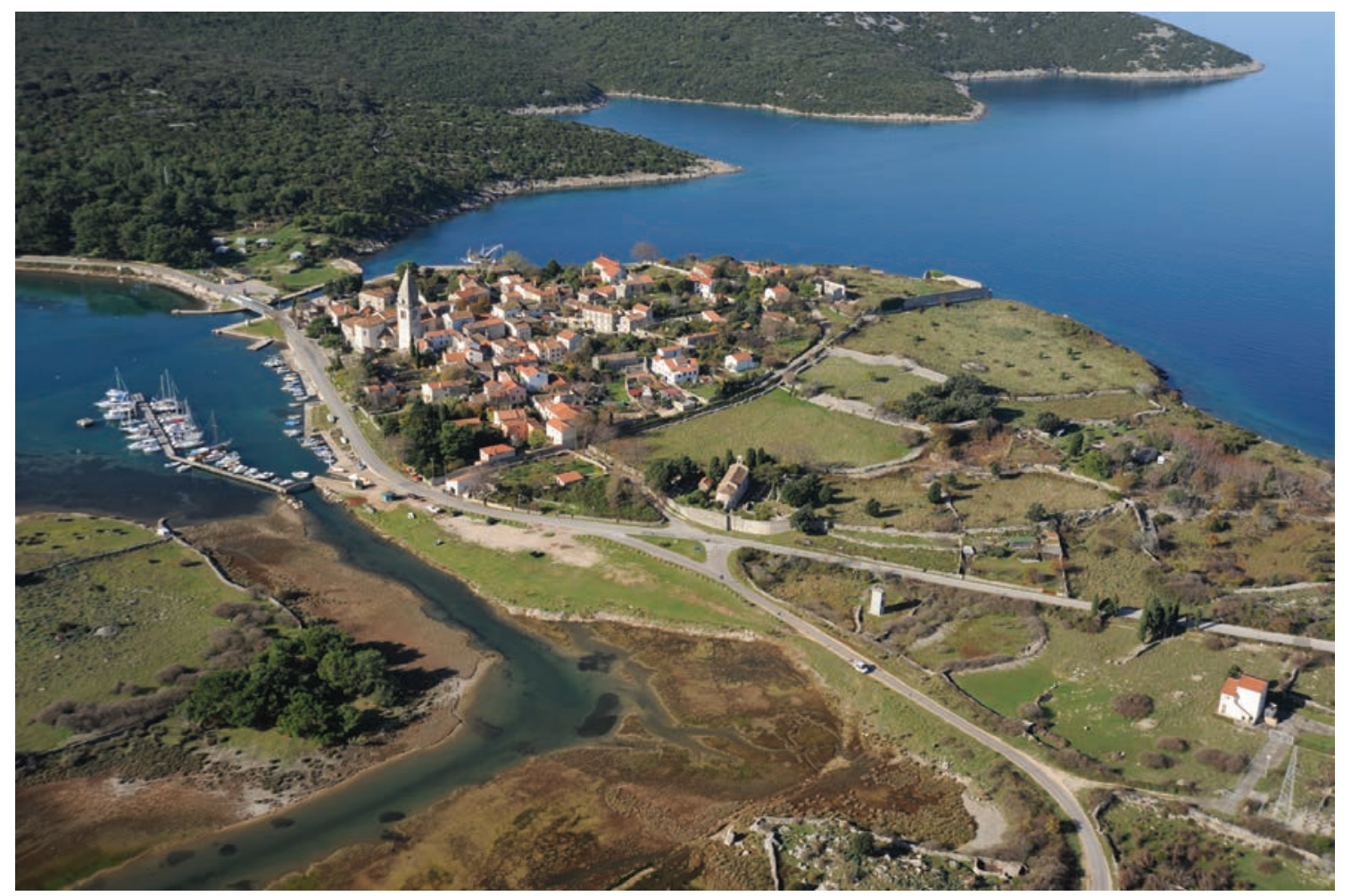

Fig. 2: The ancient city of Osor: the present village is situated in the background, while uninhabited areas of the former city and the former bay of Jaz are in the foreground. (C) Michael Doneus

Regarding the harbour, most theories actually argue for two harbours, one in the north located in the bay of Bijar (facing towards Istria) and one south-west of Osor in the bay of Jaz, now infilled (fig. 2 and 18)7. The theory of a harbour in Bijar seems to be supported by finds from underwater archaeology and submerged boat moorings ${ }^{8}$. However, due to heavy sedimentation, no archaeological proof could be found for the harbour in Jaz to date. A further unresolved issue concerns the changes of the topographic setting of Osor: it is unclear whether the area of ancient Osor was a peninsula (as it is today) or whether it could have been a small island 9 .

Knowledge about the the city's layout, function and construction phases is - from an archaeological point of view - also fragmentary. Osor has been the subject of numerous publications, but many of them have tried to summarize its complex urban development from Bronze Age to the Venetian times in a very cursory manner ${ }^{10}$. Detailed investigations have only concentrated on single aspects of Osor's (pre)history ${ }^{11}$. Among the first of such archaeological efforts to investigate the city and its surroundings was the excavation of the prehistoric and Roman necropolis outside the city wall ${ }^{12}$. During the 1950ies, interest shifted towards architectural monuments, which led to the first reflections on the layout of Roman Osor, including the considerations of its road system and the city center ${ }^{13}$. Small-scale excavations along the city wall were conducted in the 1970ies, revealing its complex stratigraphy ${ }^{14}$. It is only recently that new perspectives in archaeological research have been applied to investigations in Osor, when a Croatian-French team started to investigate the monastery of Saint Peter using ground penetrating radar, and subsequently systematically excavated its remains ${ }^{15}$. Christian monuments generally play an important role in the investigation of Osor. The oldest

${ }_{7}^{7}$ N. STRAŽIČIĆ, « Prilog poznavanju geografskih osnova lokacije, funkcije i razvoja Osora », Otočki ljetopis Cres-Lošinj, 9, Mali Lošinj, 1995, p. 79.

${ }^{8}$ A. FABER, « Osor-Apsorus iz aspekta antickog pomorstva », Diadora, 9, Zadar, 1980, p. 301 ff. Z. ETTINGER STARČIĆ, « Rekognosciranje lošinjsko-creskog podmorja. Rezultati sustavnog pregleda od 2008. do 2011. godine», Histria antiqua, 21, Pula, 2012, p. 623-631.

${ }^{9}$ A. MOHOROVIČIĆ, « Analiza razvoja urbanističke strukture naselja na otocima zapadnog Kvarnera », Ljetopis JAZU, 61, Zagreb, 1956, p. 464 and 468. A. FABER, « Osor-Apsorus iz aspekta antičkog pomorstva », Diadora, 9, Zadar, 1980, p. 298. N. Stražičić considers another opinion: N. STRAŽIČIĆ, « Otok Cres. Prilog poznavanju geografije naših otoka », Otočki ljetopis Cres-Lošinj, 4, Mali Lošinj, 1981, p. 117.

${ }^{10}$ See e.g. E. IMAMOVIĆ, Povijesno arheološki vodič po Osoru, Sarajevo, 1979.

" J. ĆUS-RUKONIĆ, «Izvori za arheologiju Cresa i Lošinja », Otočki ljetopis Cres-Lošinj, 5, Mali Lošinj, 1984, p. 229-242.

${ }^{12}$ About Iron Age see M. BLEČIĆ KAVUR, Povezanost perspektive. Osor u kulturnim kontaktima mlađeg željeznog doba. A coherence of perspective. Osor in cultural contacts during the Late Iron Age. Koper, Lošinj, 2015.

${ }^{13}$ A. MOHOROVIČIĆ, « Pregled i analiza novootkrivenih objekata historijske arhitekture na području grada Osora », Bulletin Instituta za likovne umjetnosti $J A Z U, 1-2$, Zagreb, 1953, p. 10-16.

${ }^{14}$ A. FABER, « Osor, Apsorus, antičko naselje i praistorijski ostaci », Arheološki pregled, 14, Beograd, 1972, p. 53-55. A. FABER, « Osor, antički Apsorus Istraživanje protoistorijskog i antičkog bedema i topografije grada. Nekropola iz vremena seobe naroda », Arheološki pregled, 16, Beograd, 1974, p. 79-81. ${ }^{15}$ A summary of the excavation results can be found in S. BULLY, M. JURKOVIĆ, M. ČAUŠEVIĆ-BULLY, I. MARIĆ, « Benediktinska opatija Sv. Petra u Osoru - arheološka istraživanja 2006.-2013.», Izdanja HAD, 30, Zagreb, 2015, p. 103-127. Annually published excavation reports can be found in the series Hortus artium medievalium, most recently: S. BULLY, M. JURKOVIĆ, M. ČAUŠEVIĆ-BULLY, I. MARIĆ, « Le monastère Saint-Pierre d'Osor (île de Cres): neuvième campagne d'études archéologiques », Hortus artium medievalium, 21, Zagreb, 2015, p. 356-365. DOI: 10.1484/J.HAM.5.107400. 
currently known is from late antiquity and is situated next to the church of St. Mary on the Cemetery ${ }^{16}$.

The circular layout of the city-wall was modified in the $16^{\text {th }}$ century ${ }^{17}$, when a newly built wall cut off half of the circle in the north-south direction. While the western half of the city remained populated, the eastern half became definitely and formally void of both inhabitants and most of its architectural structures. This is a clear sign of a decreasing population - a process that was already in progress in the $16^{\text {th }}$ century and continues to this day ${ }^{18}$. Otto Benndorf describes this development in his publication from 1880 as follows: "The place without the harbor thanks its historical existence to the narrow watershed of the two islands, which (...) evidently had great value in the times of predominant coastal navigation. When it lost this maritime importance, the city also lost its significance, and its modern condition offers a surprisingly bleak picture of insular ruin." ${ }^{19}$.

This "decline" of the city of Osor and its transformation into a small village presents a number of opportunities for modern archaeological research. The eastern half of the ancient city, containing a thick stratification of settlement phases, is open and accessible for archaeological investigation. As early as 1953, Andre Mohorovičić remarked: "In this empty part between the Venetian and the eastern section of the Roman wall, many walls and foundations, which are lying directly below the earth, are visible because of the poor growth of the vegetation." ${ }^{20}$. However, it took more than 60 years until these - within the scope of this publication - could be made visible using integrated archaeological prospection techniques.

\section{METHODOLOGY}

\section{Airborne laser scanning}

Airborne laser scanning (ALS), also known as airborne LiDAR (Light Detection and Ranging), is a method that has, in the past decade, greatly enhanced our knowledge about the upstanding remains of built environments, particularly in wooded areas. Using a laser scanner mounted below an aircraft, large areas can be scanned from the air resulting in highly detailed and precise digital surface and terrain models ${ }^{21}$.

Mediterranean vegetation poses a specific challenge for ALS due to its dense, low, and mainly evergreen nature. This fact requires a sophisticated data collection strategy including a well-defined choice of equipment. In our case, a full-waveform scanner was used, which discard significantly less data than conventional scanners during the data collection process and have advantages for digital terrain model (DTM) generation in vegetated areas resulting in a better quality DTM, which is essential for improving archaeological interpretation ${ }^{22}$.

When generating a detailed DTM of a coastal area, it is also desirable to combine land-based with underwater topography to reconstruct former coastlines, identify sunken archaeological structures and locate potential former harbor sites. For this task, a new generation of airborne laser scanners operating in the green region of the electromagnetic spectrum have recently become available. These have the ability to penetrate shallow water bodies in order to measure submerged topographies ${ }^{23}$. The data used for the analysis of Osor are the result of a scan that was organized to test the archaeological potential of a green laser24. Data acquisition took place at the end of March 2012, covering various small

\footnotetext{
${ }^{16}$ M. ČAUŠEVIĆ, « Sainte-Marie du cimetière d'Osor. État de la question et résultats des dernières fouilles », Hortus artium medievalium, 9, Zagreb, 2003, p. 205-212. DOI: 10.1484/J.HAM.2.305265. T. TURKOVIĆ, N. MARAKOVIĆ, « Prilog poznavanju najranije faze ranokršćanskog kompleksa Sv. Marije na groblju u Osoru », Peristil, 48, Zagreb, 2005, p. 5-18.

${ }^{17}$ Contrary to the popular opinion that the Venetian wall was built in the $15^{\text {th }}$ century, T. Sušanj Protić argues for a construction in the $16^{\text {th }}$ century: T. SUŠANJ PROTIĆ, « O urbanizmu Osora nakon 1450. godine », Ars Adriatica, 5, Zadar, 2015, p. 95-114.

${ }^{18}$ For historical reasons see N. STRAŽıČIĆ, « Otok Cres. Prilog poznavanju geografije naših otoka », Otočki ljetopis Cres-Lošinj, 4, Mali Lošinj, 1981, p. 133 ff. ${ }_{19}$ O. BENNDORF, « Ausgrabungen in Ossero », Archaeologisch-epigraphische Mittheilungen aus Oesterreich, 4, Wien, 188o, p. 74: ..."Seine historische Existenz dankt der hafenlose Ort lediglich der schmalen Wasserscheide beider Inseln, welche bei der noch jetzt gefürchteten grossen Unsicherheit des ganzen Quarnero in Zeiten vorwiegender Küstenschiffahrt offenbar einmal grossen Werth besass. Als sie diese maritime Bedeutung einbüsste, verlor auch die Stadt ihre Bedeutung und die heutigen Zustände bieten ein überraschend trostloses Bild von insularer Verkommenheit.“...

${ }^{20} \mathrm{~A}$. MOHOROVIČIĆ, « Pregled i analiza novootkrivenih objekata historijske arhitekture na području grada Osora », Bulletin Instituta za likovne umjetnosti JAZU, 1-2, Zagreb, 1953, p. 13: ...NNa tom pustom dijelu između venecijanskog i istočnog rimskog zida vidljivi su zbog nepravilnog rasta vegetacije mnogi smjerovi ziđa i temelja, koji se nalaze neposredno pod zemljom.....

${ }^{21}$ More detailed information on the method and its archaeological use can be found in M. DONEUS, C. BRIESE, « Airborne Laser Scanning in Forested Areas - Potential and Limitations of an Archaeological Prospection Technique », in D. COWLEY, ed., Remote Sensing for Archaeological Heritage Management, Proceedings of the $11^{\text {th }}$ EAC Heritage Management Symposium, Reykjavik, Iceland, 25-27 March 2010, EAC (Occasional Publication of the Aerial Archaeology Research Group, 3), Budapest: Archaeolingua, 2011, p. 53-76. S. CRUTCHLEY, The Light Fantastic. Using airborne lidar in archaeological survey, Swindon: English Heritage Publishing, 2010. J. FERNANDEZ-DIAZ, W. CARTER, R. SHRESTHA, C. GLENNIE, « Now You See It... Now You Don't: Understanding Airborne Mapping LiDAR Collection and Data Product Generation for Archaeological Research in Mesoamerica », Remote Sensing, 6 (10), 2014, p. 9951-10001. DOI: 10.3390/rs6109951.

${ }^{22}$ M. DONEUS, C. BRIESE, « Digital terrain modelling for archaeological interpretation within forested areas using full-waveform laserscanning », in M. IOANNIDES, D. ARNOLD, F. NICCOLUCCI, K. MANIA, eds., VAST 2006: The $7^{\text {th }}$ International Symposium on Virtual Reality, Archaeology and Intelligent Cultural Heritage, Nicosia, Cyprus, Eurographics Association, 2006, p. 55-162.

${ }^{23}$ M. DONEUS, N. DONEUS, C. BRIESE, M. PREGESBAUER, G. MANDLBURGER, G. VERHOEVEN, « Airborne Laser Bathymetry - detecting and recording submerged archaeological sites from the air », Journal of Archaeological Science, 40, 2013, p. 2136-2151. DOI: 10.1016/j.jas.2012.12.021.

${ }^{24}$ More information on the method as well as detailed parameters of the flight can be found in M. DONEUS, I. MIHOLJEK, G. MANDLBURGER, N. DONEUS, G. VERHOEVEN, C. BRIESE, M. PREGESBAUER, « Airborne laser bathymetry for documentation of submerged archaeological sites in shallow water », in F. MENNA, E. NOCERINO, S. DEL PIZZO, F. BRUNO, F. REMONDINO, eds., Underwater $3 D$ Recording and Modeling, XL-5/W5. Piano di Sorrento, Italy, 16-17 April 2015, Int. Arch. Photogramm. Remote Sens. Spatial Inf. Sci., XL-5-W5, 2015, p. 99-107. DOI: 10.5194/isprsarchives-XL-5-W5-99-2015.
} 
sampleareas of the Cres/Lošinj archipelago. These included Osor with parts of Punta Križa, the islands Palacol and Sv. Petar, parts of the island of Unije, and the Roman harbor site of Kolone in Istria. Each point cloud was geo-referenced and filtered. During filtering, points representing vegetation surfaces were eliminated ${ }^{25}$. The remaining point cloud represented a more or less detailed DTM displaying, amongst other relief features (e.g. karst features), and remnants of archaeological structures.

Digital vertical aerial photographs were acquired simultaneously with the airborne laser scan (fig. 3). The high-resolution images were ortho-rectified using the digital surface model from the airborne laser scan, resulting in orthoimages with a ground sampling distance of $8 \mathrm{~cm}$. The DTM, DSM and orthophotographs were imported into a GIS environment for further visualisation and interpretation. There is already abundant literature regarding archaeological visualisation

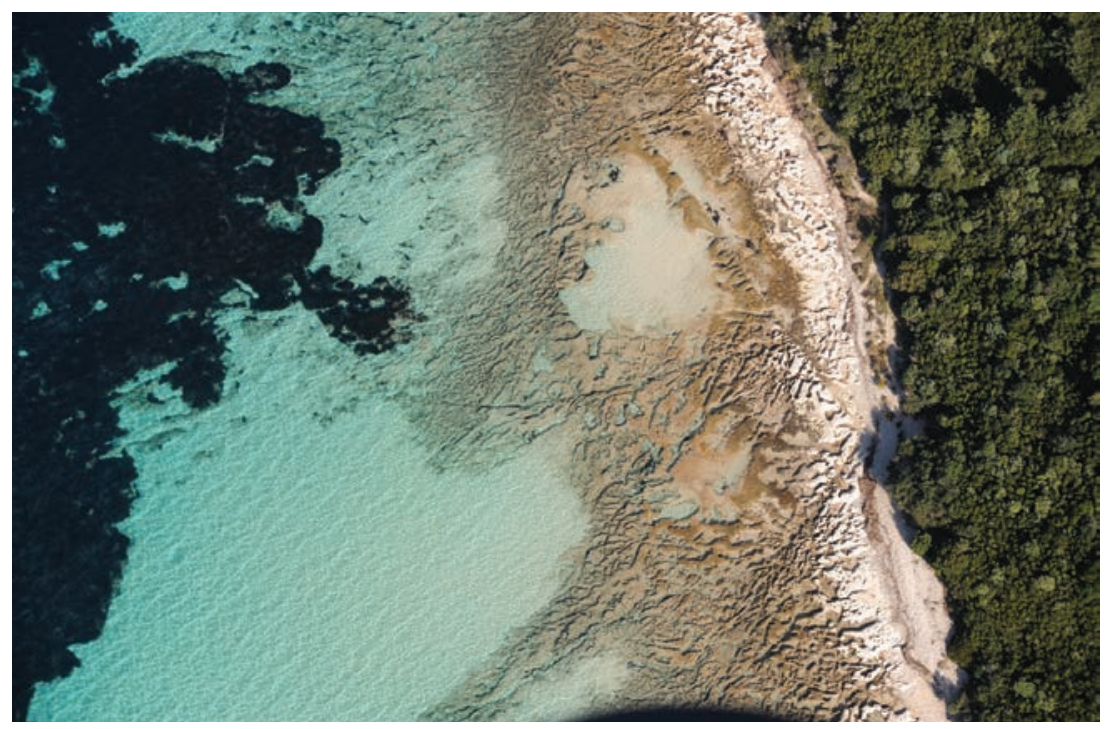

Fig. 3: Vertical aerial photographs showing the characteristic transition between land and sea in the region: the Mediterranean vegetation often connects to the narrow coastal strip, which consists of karst. (CMichael Doneus

of ALS-derived DTMs ${ }^{26}$. In this study, hillshade, slope, local relief model and positive as well as negative openness were calculated and used both exclusively and in various combinations in order to identify the boundaries of features of archaeological and environmental interest.

\section{Geophysical prospection}

Geophysical prospection uses diverse methods (geomagnetic, ground penetrating radar, resistivity and electromagnetic induction surveys) for the documentation of archaeological structures hidden in the shallow subsurface; the choice of the method depends on the soil, geology and structure of the site ${ }^{27}$. Magnetics and ground penetrating radar are currently the most frequently applied methods in the context of geophysical archaeological prospection. Furthermore, the use of motorized survey systems permits the examination of large areas quickly and cost-effectively ${ }^{28}$. While magnetic measurements are most suitable for the mapping of archaeological structures which cause anomalies in the Earth magnetic field in large, open and unobstructed areas, GPR shows its strength in the study of ancient cities and provides detailed three-dimensional information about the approximate depth, shape and location of archaeological structures.

A first application of geophysical prospection in Osor took place in the frame of the research of the monastery of Saint Peter in the year $2009^{29}$, followed by a second GPR campaign in $2011^{30}$. In these campaigns, the area adjacent to the church of St. Peter was prospected, and the results include the discovery of stone walls and other settlement features from the city past.

Large-scaled GPR surveys conducted by the LBI ArchPro took place in 2014 and 2015 on a number of parcels located east and west of the Venetian city wall (fig. 4 and 5). Parcels located east of the Venetian city (998 and 996) wall were used as agricultural land until after the Second World War; today they serve as sheep and goat pastures. Individual parcels are separated from each other by dry stone walls. These walls often have a considerable width in their lower part, since the loose stone material was collected from the fields

\footnotetext{
${ }^{25}$ A description of this process can be found at M. DONEUS, C. BRIESE, M. FERA, M. JANNER, « Archaeological prospection of forested areas using fullwaveform airborne laser scanning ", Journal of Archaeological Science, 35, 2008, p. 882-893. DOI: 10.1016/j.jas.2007.06.013.

${ }^{26}$ R. BENNETT, K. WELHAM, R. A. HILL, A. FORD, «A Comparison of Visualization Techniques for Models Created from Airborne Laser Scanned Data, Archaeological Prospection, 19, 2012, p. 41-48. DOI: 10.1002/arp.1414. Ž. KOKALJ, K. ZAKŠEK, K. OŠTIR, « Application of sky-view factor for the visualisation of historic landscape features in lidar-derived relief models ", Antiquity, 85, 2011, p. 263-273. DOI: 10.1017/Sooo3598Xooo67594. M. DONEUS, « Openness as Visualization Technique for Interpretative Mapping of Airborne Lidar Derived Digital Terrain Models », Remote Sensing of Environment, 5 , 2013, p. 6427-6442. DOI: 10.3390/rs5126427. K. CHALLIS, P. FORLIN, M. KINCEY, « A Generic Toolkit for the Visualization of Archaeological Features on Airborne LiDAR Elevation Data », Archaeological Prospection, 18, 2011, p. 279-289. DOI: 10.1002/arp.421. R. HESSE, « LiDAR-derived Local Relief Models - a new tool for archaeological prospection », Archaeological Prospection, 17 (2), 2010, p. 67-72. DOI: 10.1002/arp.374.

${ }_{27}$ W. NEUBAUER, M. DONEUS, I. TRINKS, G. VERHOEVEN, A. HINTERLEITNER, S. SEREN, K. LÖCKER, « Long-term Integrated Archaeological Prospection at the Roman Town of Carnuntum/Austria », in P. JOHNSON, M. MILLETT, eds., Archaeological Survey and the City. Oxford: Oxbow (Monograph Series, No. 2), 2012, p. 202-221. T. SAEY, M. VAN MEIRVENNE, P. DE SMEDT, W. NEUBAUER, I. TRINKS, G. VERHOEVEN, S. SEREN, «Integrating multireceiver electromagnetic induction measurements into the interpretation of the soil landscape around the school of gladiators at Carnuntum », European Journal of Soil Science, 64 (5), 2013, p. 716-727. DOI: 10.1111/ejss.12067.

${ }^{28}$ I. TRINKS, W. NEUBAUER, M. DONEUS, « Prospecting Archaeological Landscapes », in M. IOANNIDES, D. FRITSCH, J. LEISSNER, R. DAVIES, F. REMONDINO, R. CAFFO, eds., Progress in cultural heritage preservation. $4^{\text {th }}$ International Conference, EuroMed 2012, Limassol, Cyprus, October 29-November 3, Berlin, Heidelberg: Springer, 2012. Online: http://link.springer.com/chapter/10.1007/978-3-642-34234-9_3.

${ }^{29}$ I. MARIĆ, S. BULLY, M. ČAUŠEVIĆ-BULLY, M. JURKOVIĆ, « Le monastère Saint-Pierre d'Osor (Île de Cres). Quatrieme campagne d'études archéologiques ", Hortus artium medievalium, 16, Zagreb, 2010, p. 287 ff. DOI: 10.1484/J.HAM.3.23.

${ }^{30}$ M. JURKOVIĆ, M. ČAUŠEVIĆ-BULLY, I. MARIĆ, S. BULLY, « Le monastère Saint-Pierre d'Osor (Île de Cres). Sixième campagne d'études archéologiques ", Hortus artium medievalium, 18 (2), Zagreb, 2012, p. 471 ff. DOI: 10.1484/J.HAM.5.10o818.
} 

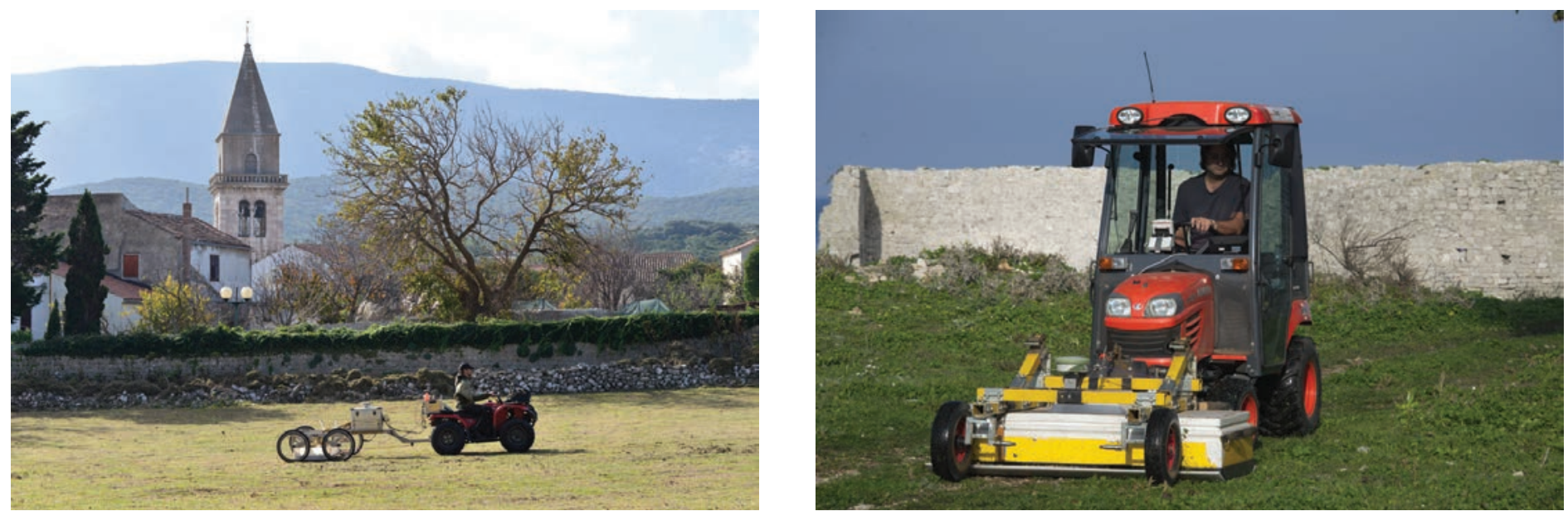

Fig. 4: High-resolution motorised GPR systems SPIDAR (upper photo) and MIRA (lower photo). (CMichael Doneus

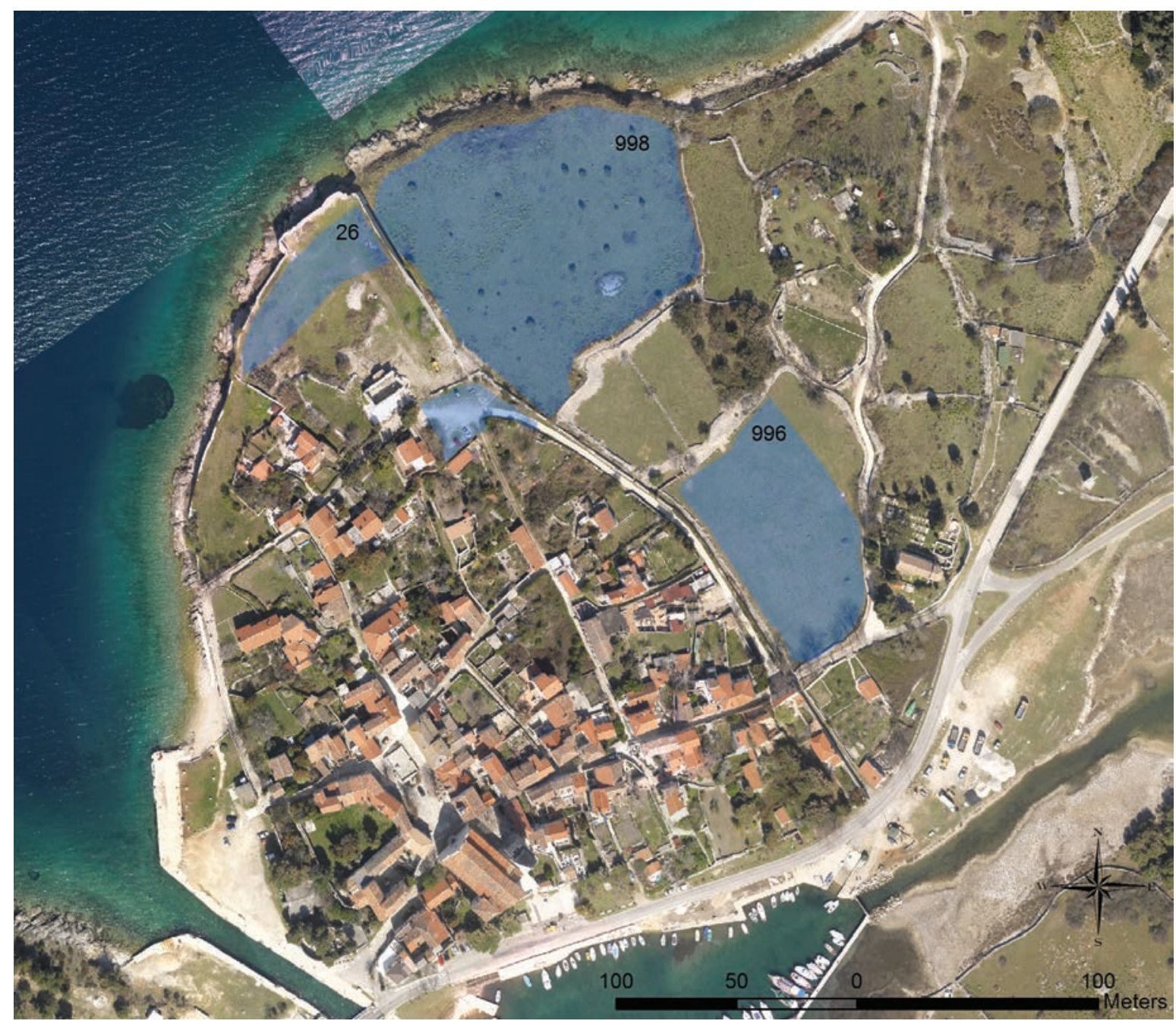

Fig. 5: Location of surveyed areas. (CLBI ArchPro.

and layered on the wall. The round structure on parcel 998 (fig. 5) is actually a large stone mound, the result of stones collected from the parcel. Due to such collecting activities, the parcels are now largely free out of building material; only ceramics and brick finds still indicate a past occupation.

In the first year, a high-resolution motorised system with six channel $500 \mathrm{MHz}$ array (SPIDAR) with $25 \mathrm{~cm}$ cross-line spacing was used on the parcel 996. In the second year a 16 channel $400 \mathrm{MHz}$ MALÅ Imaging Radar Array (MIRA) with $8 \mathrm{~cm}$ cross-line spacing was applied on parcel 26 and 998. Altogether an area of 1.8 ha was documented in 3 working days. To obtain exact geographic positioning, an RTK-GNSS system, which is also linked to a real-time navigation software was in use. The processing and visualisation of the collected data was carried out using the software ApRadar, a collaborative in-house development of the LBI ArchPro and its partner ZAMG.

\section{RESULTS}

\section{ALS/ALB}

Approximately 29 square $\mathrm{km}$ of land and underwater terrain were scanned in the vicinity of Osor (fig. 6). The high 


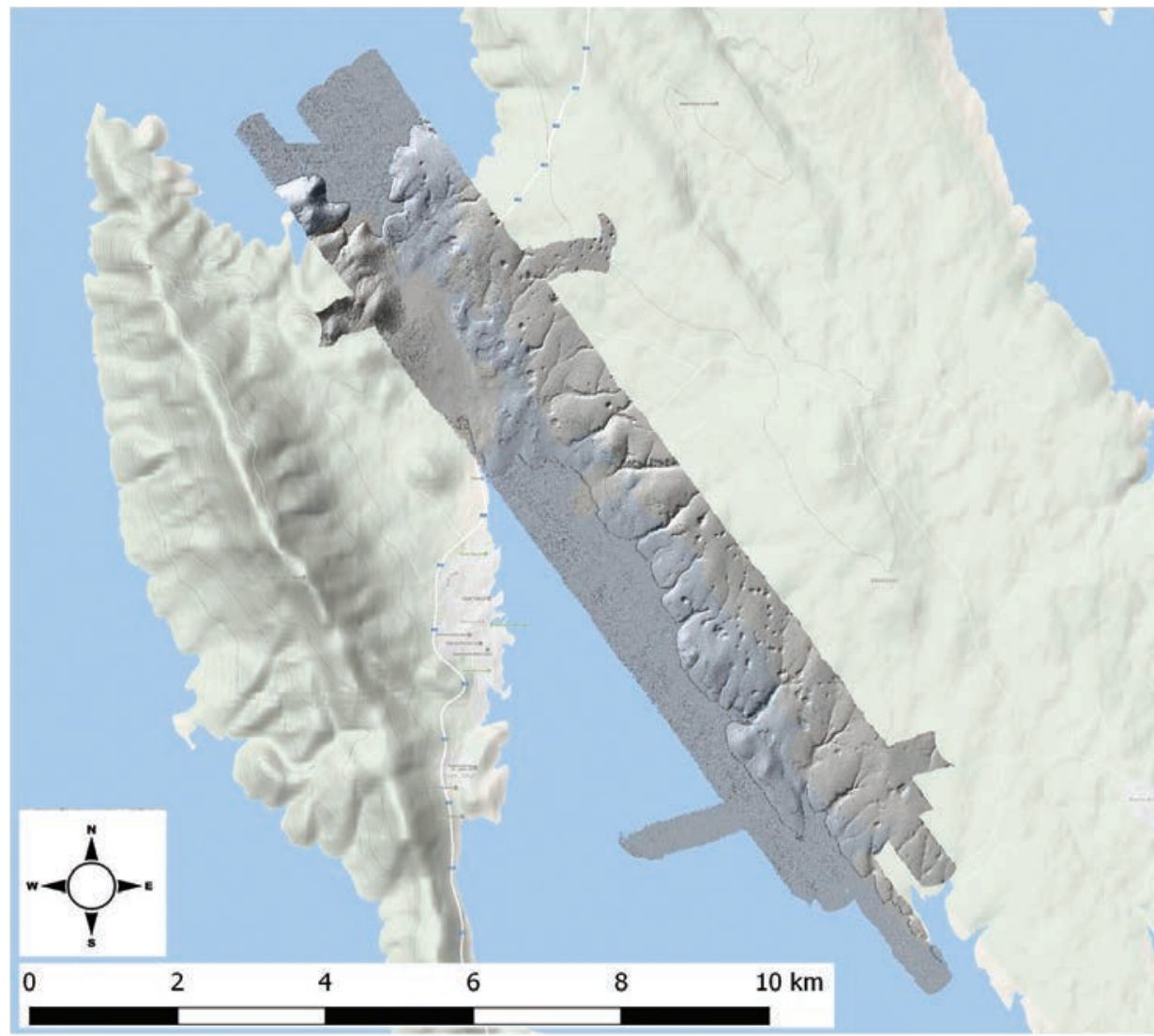

Fig. 6: Osor and Punta Križa - area covered by the airborne laser scan from March, 29, 2012. (C) LBI ArchPro.

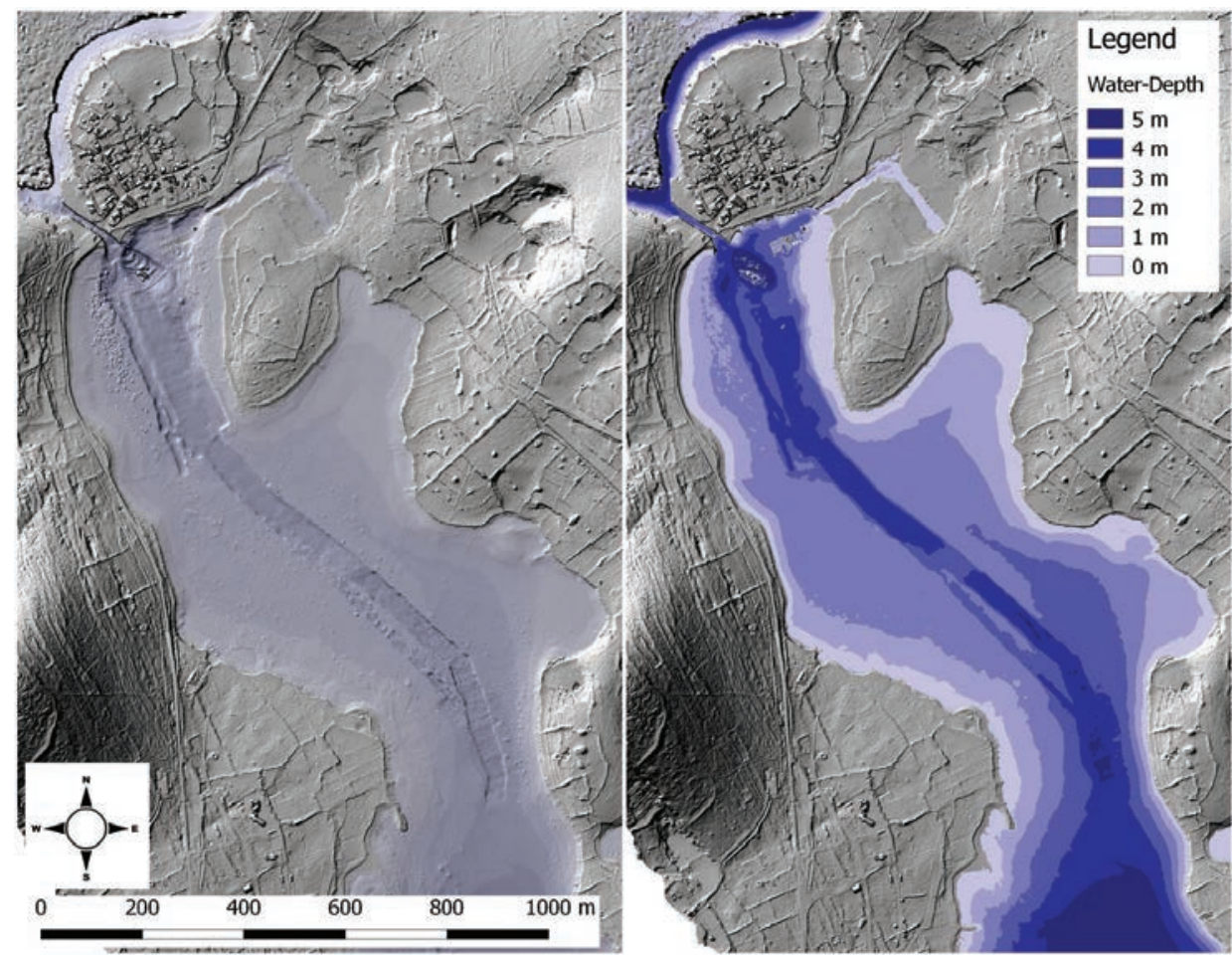

Fig. 7: Osor and its bay. Digital terrain model (combination of slope and hillshade) derived from ALS/ ALB. Left: Underwater areas depicted in transparent blue color. Right: map of water depth in the channel of Osor. (CLBI ArchPro

point density of the scans allows for the generation of raster data products at a resolution of $0.25 \mathrm{~m}$. The area includes the village of Osor and its bay, as well as the coastal area of Punta Križa south-east of Osor. Penetration depth of the green laser into the water surface amounts to 12-14 $\mathrm{m}$. This is a result of optimal water clarity (fig. 3) and smooth surface during the time of acquisition.

The ALS/ALB data clearly show that the water in the bay of Osor is extremely shallow (depths range between 3 and $5 \mathrm{~m}$ below water surface), a fact which causes problems for shipping to the present day, since sediments continuously fill the fairway channel (fig. 7). This was one of the reasons for the decline of the city in the Middle Ages ${ }^{3}$ : neither the size of the channel nor the depths of the sea were suitable for the increasing size of the ships. The linear features, which are deeper areas under water and therefore depicted in dark blue in fig. 7, are areas that have been dug out (dug-out-depth is between 1 and $1.5 \mathrm{~m}$ ) in an attempt to oppose the silting of the bay and create a lasting and deeper fairway channel. Several attempts can be distinguished in the form of parallel and partly intersecting "ditches". In addition to the ditches, remains of modern supply lines and underwater vegetation (which could not be filtered) can be seen. The deep oval area south-east of the artificial channel is a "natural" deepening, where sediment is removed due to the strong currents that can occur in the artificial channel.

In the city of Osor, ALS did not provide any new insights, as the territory is completely overbuilt. The only new feature is a linear structure running in a perpendicular way towards the middle of the artificial channel. This may be related to the old bridge, which was previously situated in the middle of the channel ${ }^{32}$. Archaeological underwater activities in conjunction with recent construction works in this area in the fall of 2014 also yielded little new information.

Any coastline is subject to changes due to rise and fall of the sea-level, natural processes of erosion and accumulation, and human intervention. Sea-level change is not a modern phenomenon. Archaeological and geological investigations show that the modern sea level in the Adriatic is up to $2 \mathrm{~m}$ higher than during Roman times ${ }^{33}$. The effect of a changing sea level can be modeled in GIS (fig. 8). This simulation is, however, based

\footnotetext{
31 N. STRAŽIČIĆ, « Otok Cres. Prilog poznavanju geografije naših otoka », Otočki ljetopis Cres-Lošinj, 4, Mali Lošinj, 1981, p. 134.

${ }^{32}$ See, for example, old map of Osor in T. SUŠANJ PROTIĆ, « O urbanizmu Osora nakon 1450. godine », Ars Adriatica, 5, Zadar, 2015 , fig. 9.

${ }_{3}$ S. FAIVRE, E. FOUACHE, V. KOVAČIĆ, S. GLUŠĆEVIĆ, « Geomorphological and archaeological indicators of Croatian shoreline evolution over the last two thousand years », GeoActa, Special Publication, 3, 2010, p. 125-133.
} 


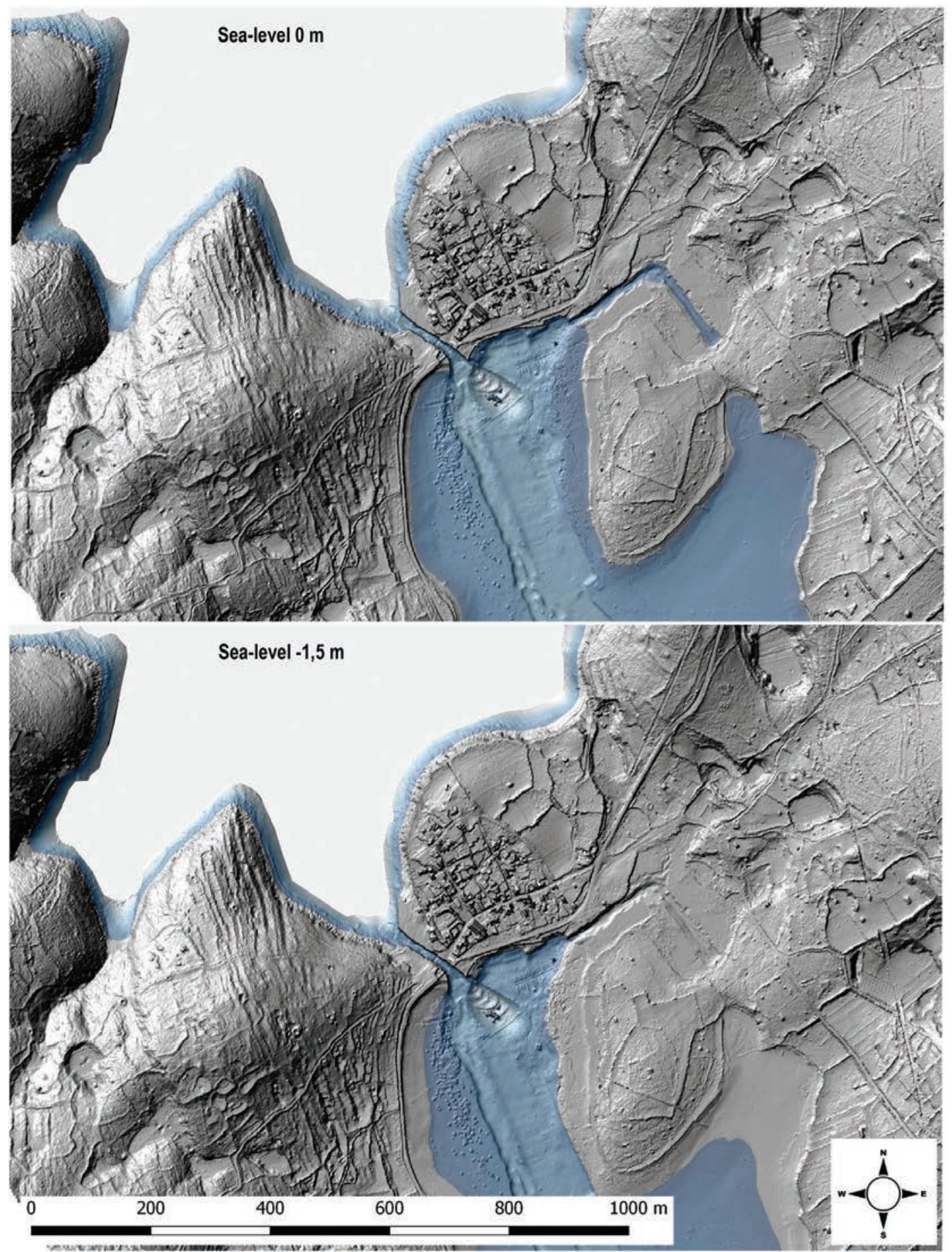

Fig. 8: Sea-level change modeled in GIS. The upper part of figure displays today's situation as resulted from the ALS/ $A L B$ derived DTM. In the lower part a fall of the sea-level by $1.5 \mathrm{~m}$ is simulated. CLBI ArchPro coastline north of Osor - due to the greater depth or rather steeply descending topography under water - did not change significantly despite the rising sea level. On the other hand, the former bay of Jaz, situated south-west of the city, is not visible in fig. 8 , due to massive landscape changes in the last 100 years (see also fig. 2 and 18 ). The simulation also shows that the width of the natural channel south of Osor has been very narrow (some $200 \mathrm{~m}$ ). Its depth in ancient times cannot be determined without further geoarchaeological investigations, since the continuous sedimentation has changed the underwater topography completely.

In addition to the underwater topography, the ALB-data could be used to derive digital terrain models that are cleared of vegetation. While dense Mediterranean vegetation obscures any archaeological site on the orthophotograph (fig. 9, left), the DTM (fig. 9, right) clearly shows archaeological and historical landscapes containing terraces, pathways, dry stone walls, a fortified settlement, and lime kilns - parts of the man-made landscape that is still preserved under the Mediterranean vegetation. These results clearly demonstrate that using ALS/ALB in Mediterranean environments bears great archaeological potential.

A comparison between the topographic map and the DTM shows the quality of results on today's topography, which differs from the Roman one especially in the moist area north-east and east of Osor. This area was subject to human intervention, when inhabitants took measures in the recent past to drain it together with the bay of $\mathrm{Jaz}^{34}$. Together with already risen sea level, this had a lasting effect on the outline of the coastline. The upper part of fig. 8 displays today's situation as modeled from the ALS/ ALB derived DTM. In the lower part of fig. 8, a fall of the sealevel by $1.5 \mathrm{~m}$ is simulated. This simulation shows that the generated with ALS/ALB (fig. 10). While only a few landscape features are documented on the topographic maps of the peninsula in the bay of Sonte the DTM shows the actual, far more structured topographic situation. Furthermore, in the areas with Mediterranean vegetation, the use of aerial photography is often restricted because the vegetation is too dense and evergreen ${ }^{35}$. Archaeological structures are only visible in the ALS, as is the small church of St. Platon ${ }^{36}$ (fig. 11).

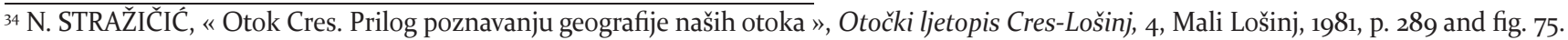

${ }^{35}$ For the region, however, the following publication should be mentioned: B. ŠILJEG, Proučavanje kasnoantičke naseljenosti Hrvatskog primorja primjenom metode daljinskog istraživanja (Late antiquity settlements research in the Croatian Littoral with the application of the remote sensing method). Doctoral thesis. University of Zagreb, 2006.

${ }^{36}$ See last M. ČAUŠEVIĆ-BULLY, S. BULLY, «Esquisse d'un paysage monastique insulaire dans le nord de l'Adriatique. L'archipel du Kvarner (Croatie) », Hortus artium medievalium, 19, Zagreb, 2013, p. 169 f. DOI: 10.1484/J.HAM.1.103576.
} 


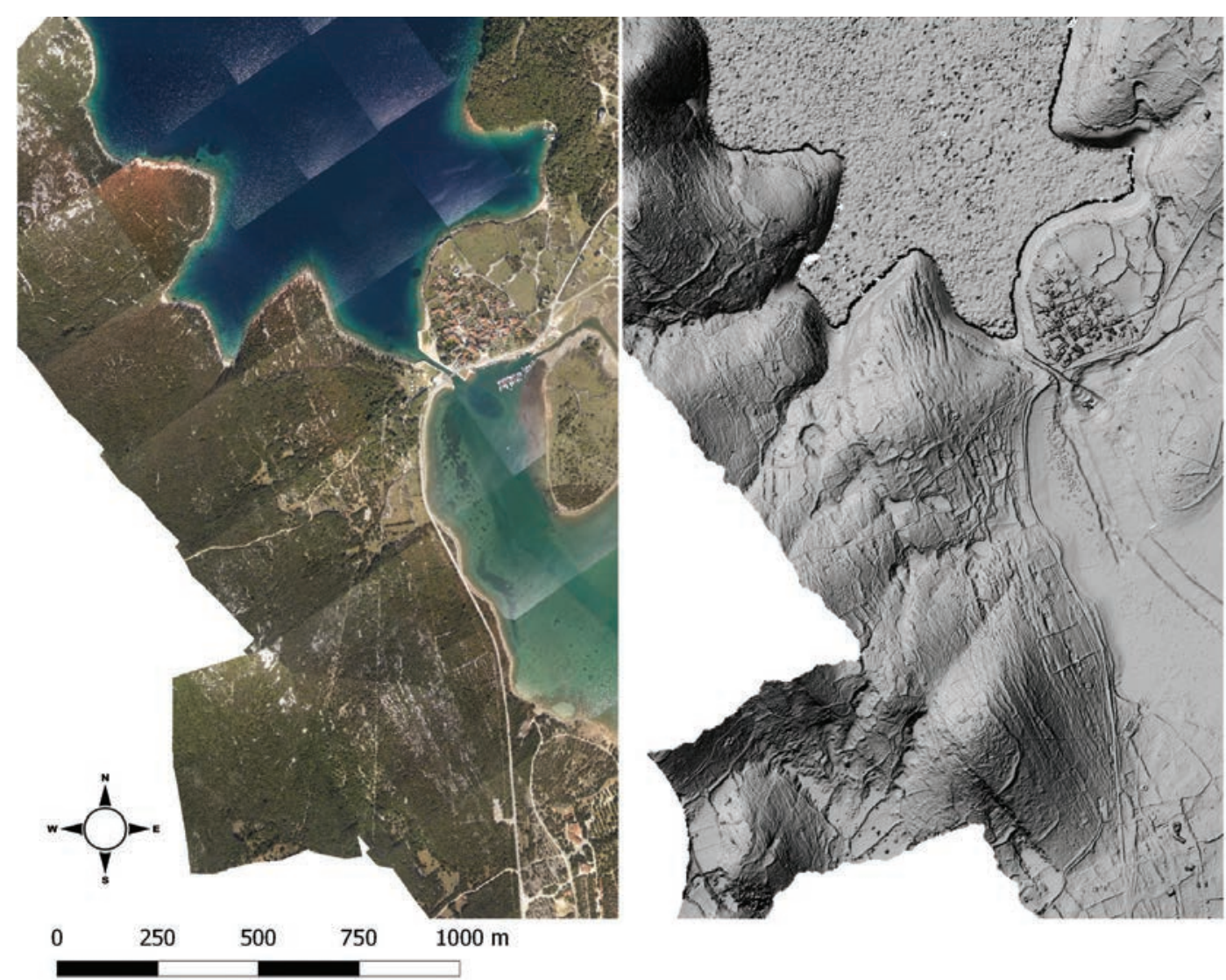

Fig. 9: Osor and coastal area of the island of Losinj. The filtered digital terrain model gives a detailed view of the topography and its micro relief with a broad range of natural (especially karstic features) and human structures (hillforts, terraces, dry-stone walls, lime kilns, etc.). Left: orthophotograph, right: visualization of DTM as combination of slope and hillshade. (CLBI ArchPro

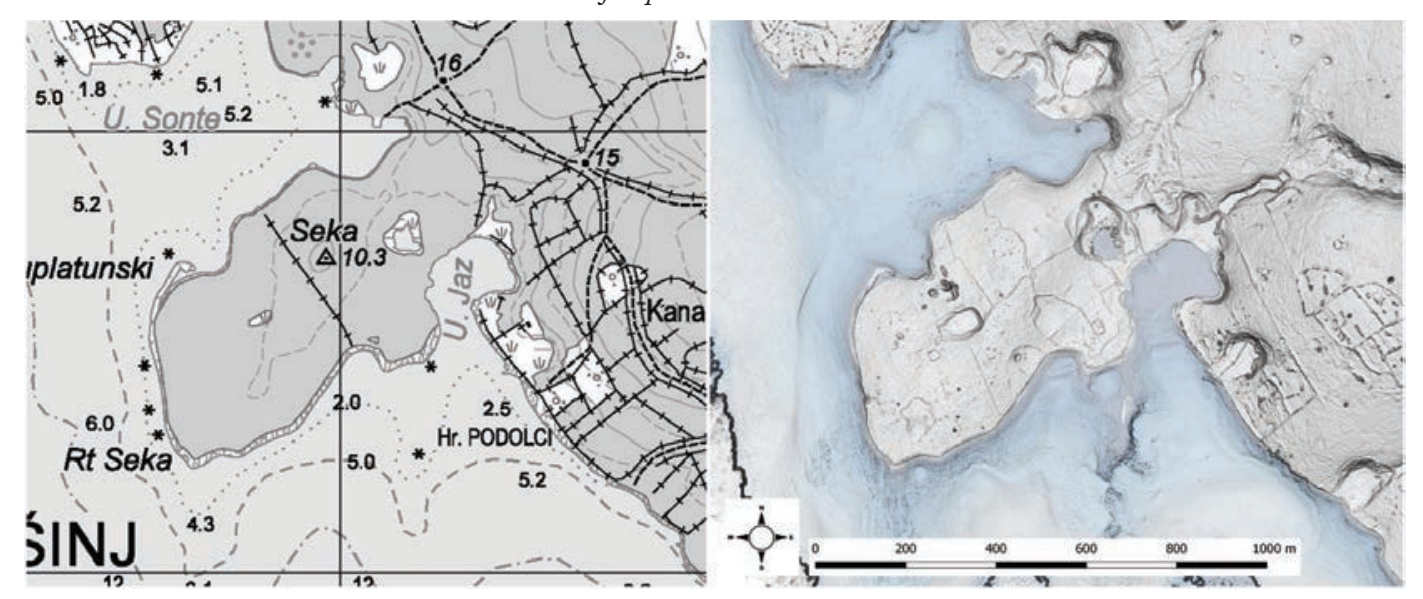

Fig. 10: A comparison of the topographic map (left) and the digital terrain model which is cleared of vegetation (right) and shows many more features in the landscape in a more detailed level. (CLeft: Državna geodetska uprava Republike Hrvatske. Right: LBI ArchPro.

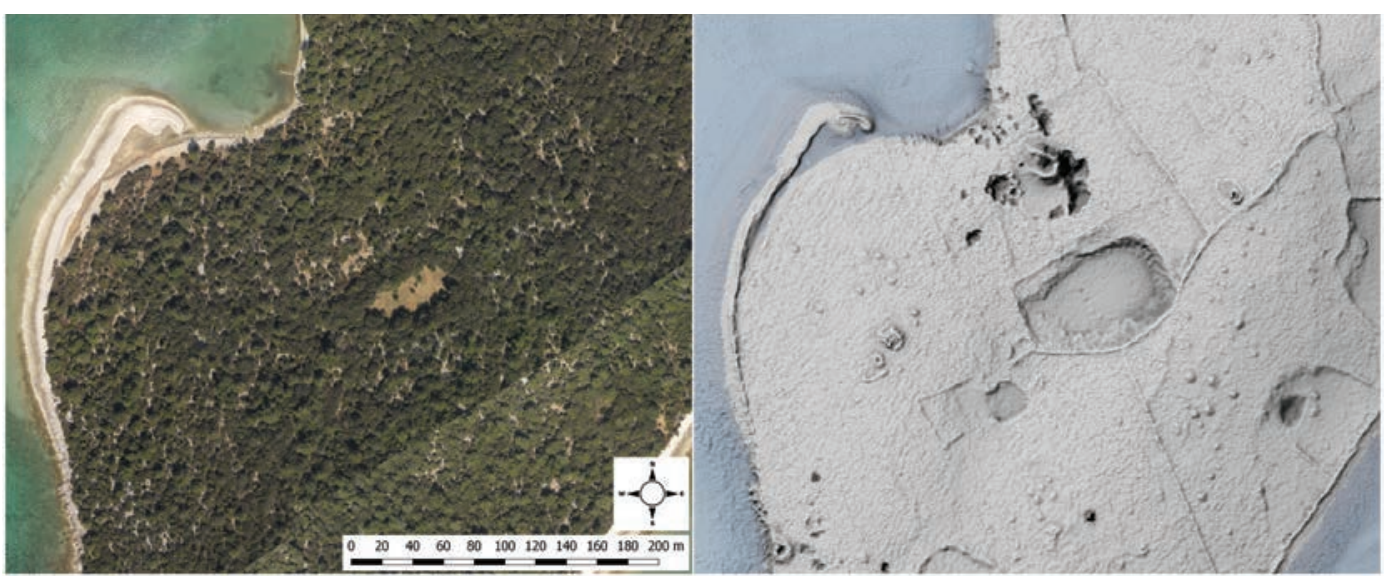

Fig. 11: Left: Orthophoto of the area showing dense Mediterranean vegetation. Right: ALS-derived DTM after archaeological filtering showing the church of Saint Platon. (CLBI ArchPro 


\section{Ground penetrating radar}

As mentioned above, Osor has a long history of urban development, which GPR is helping us to decipher. The modern city stands on a massive stratification, which is recognizable on the northern slope of the city. Here, north and north-east winds have removed the city wall almost completely (fig. 17). This has revealed a thick package of cultural strata that, according to its associated finds, begins in prehistoric times. Also, accidental discoveries, such as the prehistoric grave in the area of the monastery of Saint Peter, confirm the preservation of prehistoric strata ${ }^{37}$.

As with any other prospection method, the visibility and detectability of archaeological traces depends on many factors (e.g. salinity, moisture, degree of accumulation / erosion, compactness of covering deposits). For instance, in some areas, measurements on the same day using the same GPR antenna produced completely different results in two adjacent areas. While buildings are clearly visible in the data on the plot east of the Venetian wall (parcel 998, fig. 5), on the opposite side of the wall (parcel 26) almost no archaeological traces could be documented (fig. 12). The reason for this could be related to the fact that the eastern and western parts of the city had a different development through the centuries. Better visibility of archeological structures is apparent in the eastern part of the city - the same part where the settlement activities stopped almost 500 years ago. The western part, on the other hand, has undergone changes and numerous construction activities during that period, which seems to have left a lasting influence on the visibility of archaeological structures.

The appearance of older building phases in the GPR data can also be influenced by other factors. Good visibility parallel and very close to the northern boundary of the city (parcel 998) has to do with a high degree of erosion. The protective wall of the city has been eroded by the wind and weather, thus the stone walls are already visible near the surface. This is exactly the opposite environmental situation of the lowest part of the parcel 996 (fig. 14). The poor visibility of the building structures is probably due to the accumulation of soil, since in the lowest part of the parcel the walls are visible from $0.8 \mathrm{~m}$ depth. The height difference from the northern city border to the south part of the parcel 996 amounts to more than $10 \mathrm{~m}$ and this has certainly caused more earth material to accumulate in the lower parts of the relief.

There are further reasons for the low visibility of stone walls at the western part of parcel 998, located next to the Venetian wall. The lack of the stone walls is noticeable especially in the area where the calcareous subsoil (grown soil) already lays $1.5 \mathrm{~m}$ under the topsoil (fig. 13). This is probably also the main reason for the lack of wall foundations in the data.

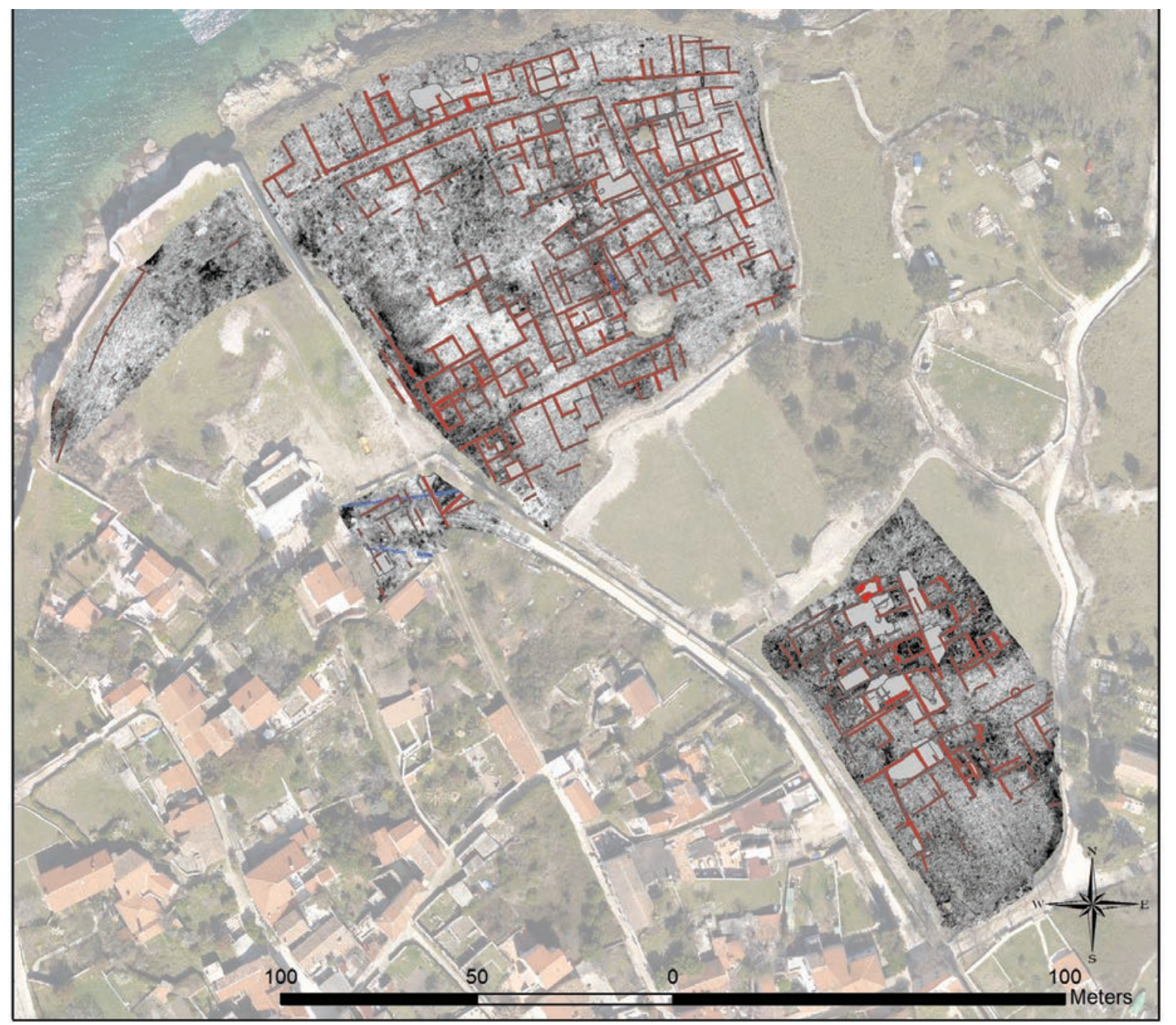

Fig. 12: Radargram and a general interpretation of the GPR data: walls (red), floors (gray) and water/power supply lines (blue). (CLBI ArchPro

37 I. MARIĆ, S. BULLY, M. ČAUŠEVIĆ-BULLY, M. JURKOVIĆ, « Le monastère Saint-Pierre d'Osor (île de Cres). Quatrieme campagne d'études archéologiques », Hortus artium medievalium, 16, Zagreb, 2010, fig. 4. DOI: 10.1484/J.HAM.3.23. 


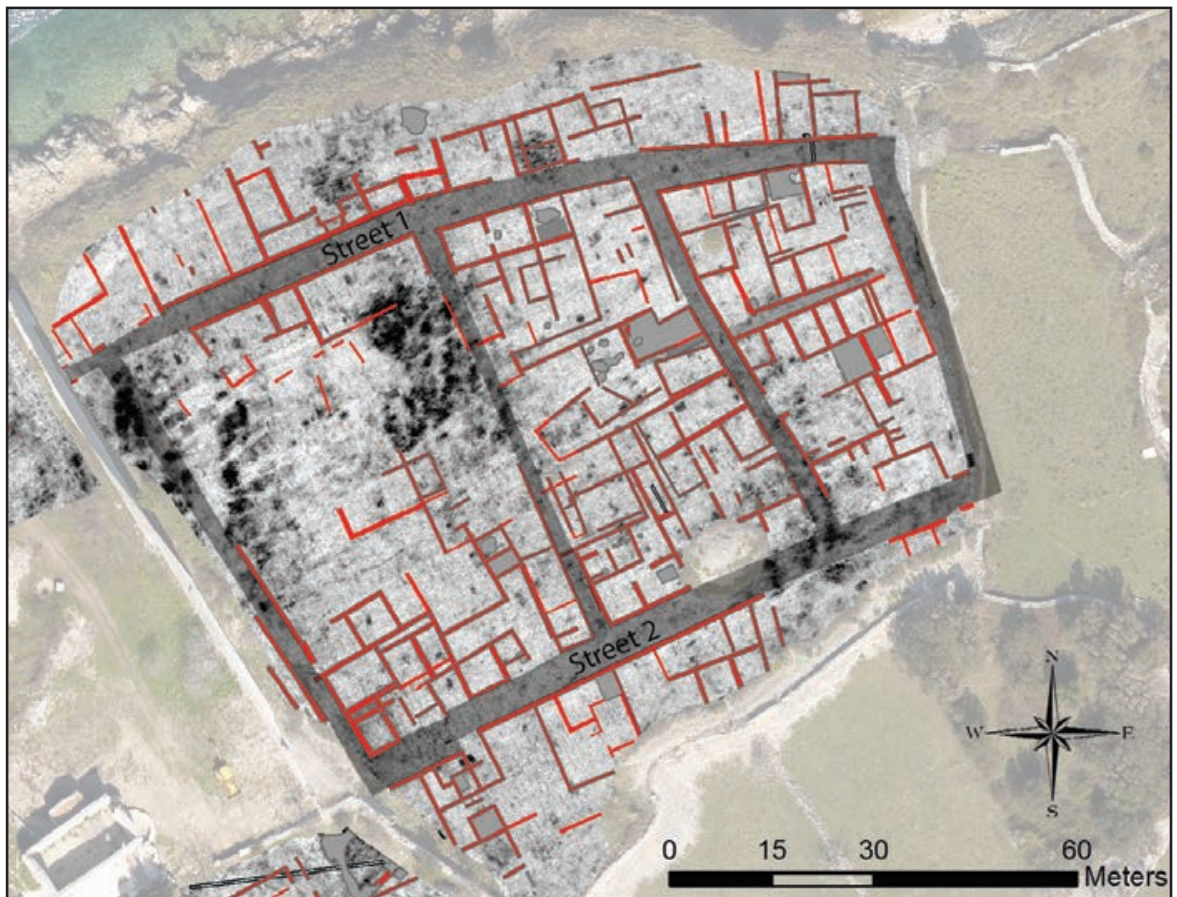

Fig. 13: Interpretation of the GPR results from the parcel 998. In the background a depth slice 1.5$2.0 \mathrm{~m}$, in the foreground streets (gray), buildings (red) and floors (light gray). (CLBI ArchPro

The long-lasting development of Osor is reflected in the prospection results, which do not reveal a single phase but a palimpsest of repeated building activities. Some of the features are also of modern origin like water/power supply lines or small-scaled trenches from the Second World War. But most of the documented urban structures that can be seen in the radargram - walls of stone buildings and numerous reflecting and absorbing layers (floors, walls, roads etc.) - can be dated to times after the Roman takeover of the city. Excavations in the area of the church of St. Peter have revealed Roman settlement features, which have the same orientation as the structures visible in the GPR data ${ }^{38}$. The radargram is visually dominated by stone foundations as well as pavements and other floor coverings. These have a massive appearance and are superimposed upon older prehistoric settlement structures, which were built in a less compact way and therefore are not visible ${ }^{39}$.

Among the most prominent features to manifest in the GPR data are roads (fig. 13). The GPR data reveals a street pattern that defines the layout of the ancient city. One of the most prominent roads runs parallel to the city wall (Street 1 ). It could be documented along roughly $120 \mathrm{~m}$ in the northern part of parcel 998. In parcel 26 (western of the Venetian city wall), it becomes invisible (fig. 12). However, its probable course is indicated by a few stone walls. The road, approx. $4 \mathrm{~m}$ wide, originally ran in a distance of about $30 \mathrm{~m}$ parallel to the norther city wall. The radar data do not show many traces of pavement and water channels, which are normally

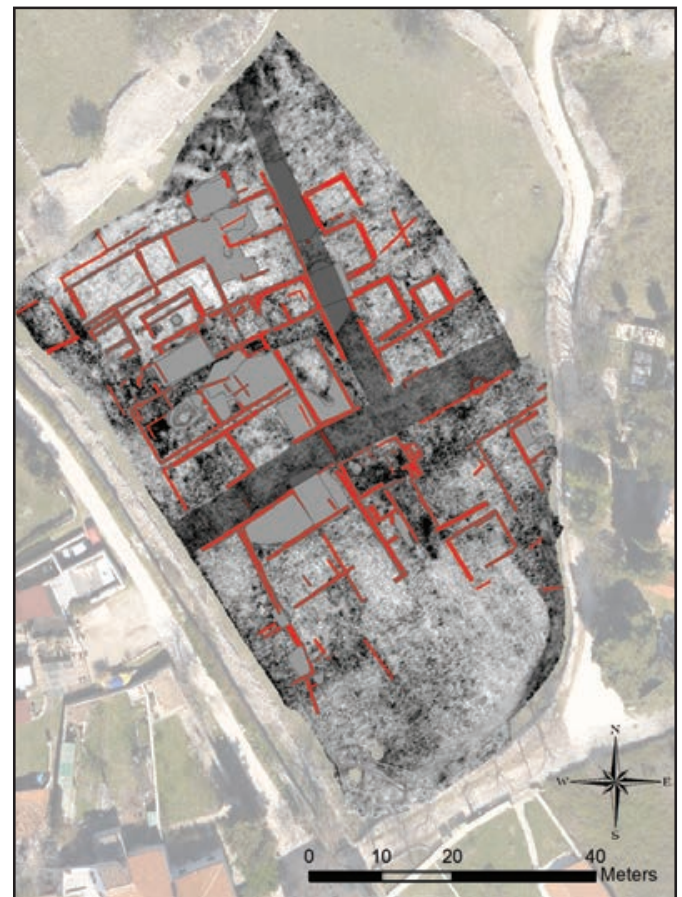

Fig. 14: The GPR results from the parcel 996 and the interpretation. In the background a depth slice 0.75-1.0 $m$, in the foreground streets (gray), buildings (red) and floors (light gray). (CLBI ArchPro

accompanying major roads. In a distance of $60 \mathrm{~m}$, another major road is running parallel in east-west direction (Street 2). Both are interconnected by three smaller, north-south directed streets. The width of these connecting streets is less than $3 \mathrm{~m}$. In the southern part of plot 996, the street grid seems to be extended (fig. 14). The excavated remains of a street, which was mentioned by Aleksandra Faber in $1982^{40}$, is probably part of the circular course (Street 1 ) from the GPR data.

The road network is the starting point for the shape and size of individual residential areas (insulae). Only three insulae are completely captured by the GPR measurements (fig. 13). Due to the bent course of the Street 1, their layout is not exactly rectangular. The insulae are further divided by smaller back-roads, which allow access to different parts of buildings. Within the insulae, individual building complexes are clearly visible. Although it can be assumed that the buildings are part of a residential area, important information that would provide a more detailed assessment of their individual function is in large part missing: the radar data do not show many traces of heating systems or water supply. Such information would allow for a more detailed interpretation of the use of each building ${ }^{41}$. However, different floors are visible in individual rooms. Depending on the material of the floor (brick or stone), they are recognisable in the GPR data as reflective or absorbing layers.

${ }^{38}$ S. BULLY, M. JURKOVIĆ, M. ČAUŠEVIĆ-BULLY, I. MARIĆ, « Benediktinska opatija Sv. Petra u Osoru - arheološka istraživanja 20o6.-2013. », Izdanja $H A D$, 30, Zagreb, 2015, fig. 4 .

${ }^{39}$ The prehistoric necropolis, which M. Blečić Kavur noted in the northern part of parcel 998, is not visible in the GPR data: M. BLEČIĆ KAVUR, Povezanost perspektive. Osor u kulturnim kontaktima mlađeg željeznog doba. A coherence of perspective. Osor in cultural contacts during the Late Iron Age. Koper, Lošinj, 2015, fig. 15.

${ }^{40}$ A. FABER, « Počeci urbanizacije na otocima sjevernog Jadrana », Izdanja HAD, 7, Zagreb, 1982, p. 65.

${ }^{41}$ Modern high-resolution GPR systems are able - under favourable conditions - to document infrastructure elements such as water supply and disposal, heating etc. See e.g. hypocaust system at the Roman forum of Carnuntum: W. NEUBAUER, M. DONEUS, I. TRINKS, G. VERHOEVEN, A. HINTERLEITNER, S. SEREN, K. LÖCKER, « Long-term Integrated Archaeological Prospection at the Roman Town of Carnuntum/Austria », in P. JOHNSON, M. MILLETT, eds., Archaeological Survey and the City. Oxford: Oxbow (Monograph Series, No. 2), fig. 9.10. 


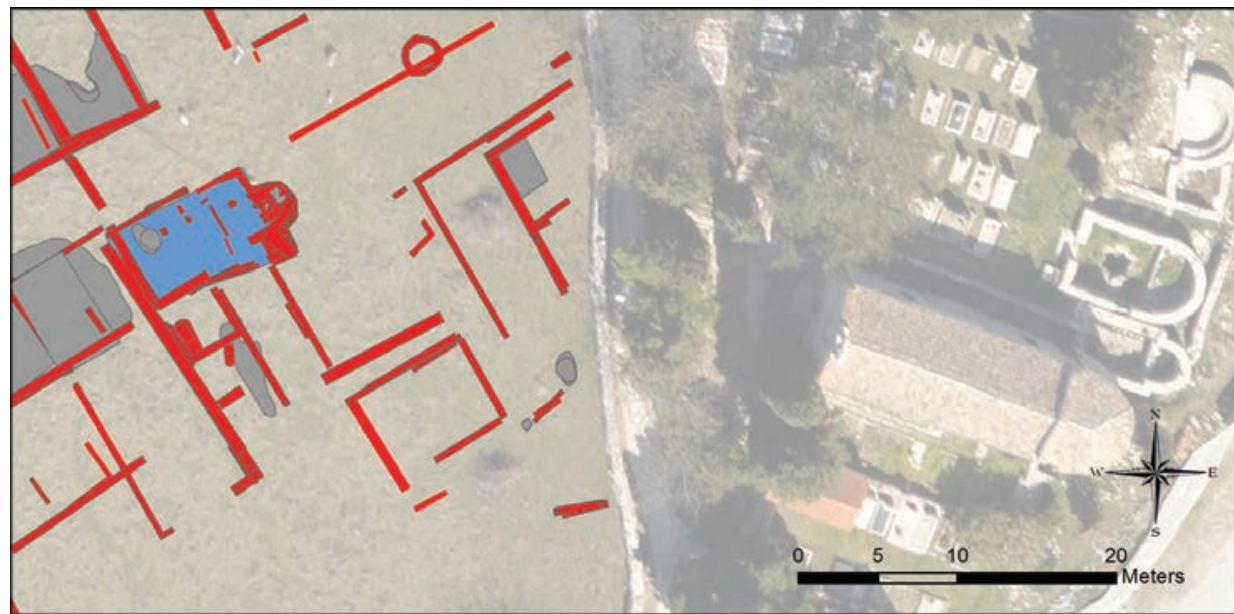

Fig. 15: A newly discovered small church on parcel 996 (left) is located about $50 \mathrm{~m}$ west of the late antique Christian complex next to the church of St. Mary on the Cemetery (right). (CLBI ArchPro measured by a Croatian-French team in $2011^{43}$. As it was the assembling area for the geophysical equipment from the 2015 campaign, it was re-measured to test the setup of our system. Similar results were obtained in both cases, although GPR systems of different type and frequencies were used. In 2011, the documented stone walls were primarily set into a context with the monastery and used as a base for its reconstruction ${ }^{44}$. There are two other walls, however, which appear interesting for a context of Venetian building activities (fig. 16). These are solid stone foundations next to the Venetian city wall, which have a width of ca. $1 \mathrm{~m}$ and reach a depth of over $2.5 \mathrm{~m}$. They are built on top of antique constructions that are

In addition to the supposedly Roman and post-Roman settlement features, a newly discovered Christian monument could be documented on a parcel 996 (fig. 15). The small church has a total length of $10.5 \mathrm{~m}$ (including the $1 \mathrm{~m}$ long apse) and a width of $6 \mathrm{~m}$. The data seem to suggest the presence of more than one nave. In front of the apse, reflective layers hint at the remains of an altar. Its walls overlay at least one older city phase and are probably overlapping one of the streets. However, the simple layout of the church makes its precise dating exclusively with the GPR results impossible. Such small Christian monuments start to be built in the late antiquity and are still common in the region ${ }^{42}$. Due to its spatial position outside of the today's resident area, however, a construction period between late antiquity and the $16^{\text {th }}$ century seems likely.

The small parking lot lying next to the Venetian wall and next to the church of St. Peter (fig. 5) has already been visible from $0.8 \mathrm{~m}$ upwards and are thus partly preserved. The two massive walls apparently form an annex to the city wall from the $16^{\text {th }}$ century. The annex has a trapezoidal form with approx. $10 \times 13 \mathrm{~m}$. The massive construction and the alignment with the city wall indicate a first interpretation as a Venetian tower. A map from the end of the $16^{\text {th }}$ century does depict a tower on the same position ${ }^{45}$, but further investigations would be needed to prove this thesis. If, however, one compares this information with the oldest cadastral plan from Osor, dated to 1821, it is noticeable that a stone building is indicated in this spot instead of a tower ${ }^{46}$. From an archaeological point of view, the annex foundations seem to be too massive for a simple building. If the interpretation is correct, then the tower seems to have eventually lost its primary function and the remains were used for a secondary purpose ${ }^{47}$.

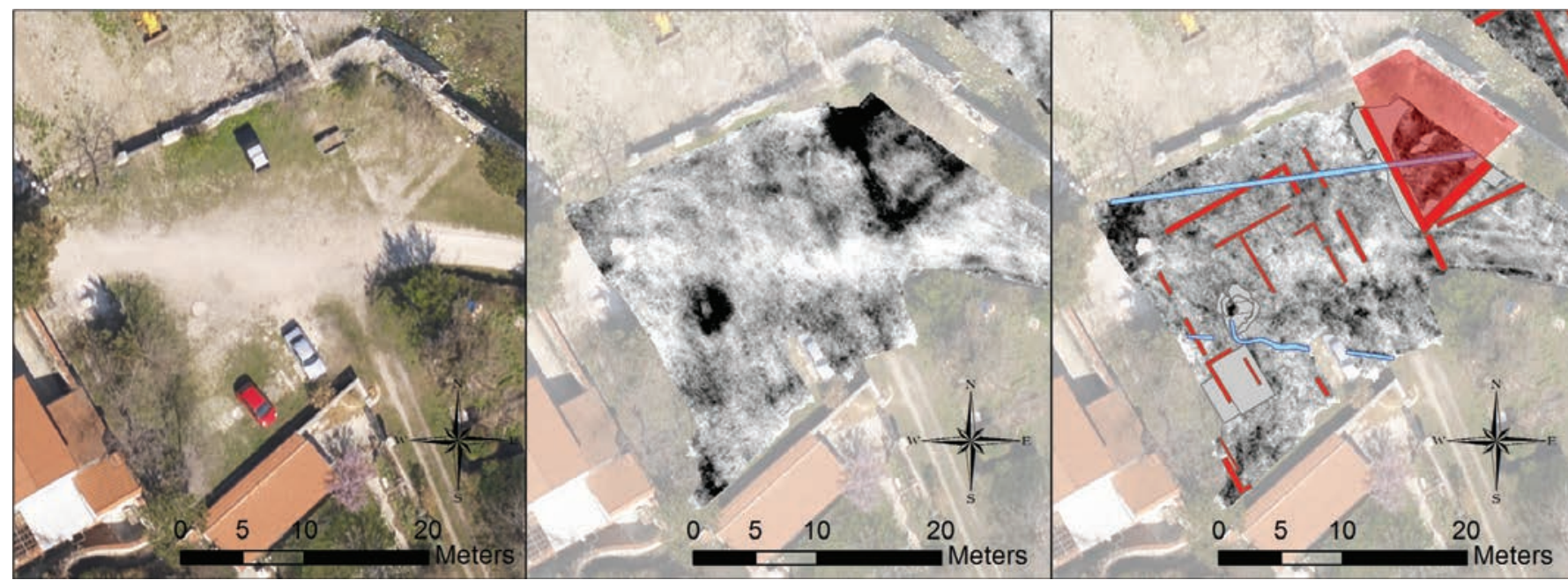

Fig. 16: Massive stone foundations next to the Venetian city wall which form a $10 \times 13$ m large annex. Left: Orthophoto. Middle: GPR depth slice 1.0-1.5 m. Right: Depth slice 0-0.5 $\mathrm{m}$ with the interpretation (walls in red, floors in grey, water and power supply lines in blue) and indicated location of the Venetian tower. CLBI ArchPro

\footnotetext{
$\overline{{ }^{2} 2}$ For the archipelago of Cres/Lošinj, 75 small churches and chapels, most of them with a very simple ground plan, were last counted: M. DLAČIĆ, Crkve i kapele cresko - lošinjskog arhipelaga, Mali Lošinj, 2016.

${ }^{43}$ M. JURKOVIĆ, M. ČAUŠEVIĆ-BULLY, I. MARIĆ, S. BULLY, « Le monastère Saint-Pierre d'Osor (Île de Cres). Sixième campagne d'études archéologiques », Hortus artium medievalium, 18 (2), Zagreb, 2012, p. 471 ff. DOI: 10.1484/J.HAM.5.100818.

${ }^{44}$ See above.

${ }^{45}$ M. PAVIĆ, « Plovidbena ruta sjevernim Jadranom u Izolaru Giuseppea Rosaccija », Rad. Zavoda povij. znan. HAZU u Zadru, 42, Zagreb - Zadar, 2000 , fig. 6.

${ }^{46}$ T. SUŠANJ PROTIĆ, « O urbanizmu Osora nakon 1450. godine », Ars Adriatica, 5, Zadar, 2015, fig. 11.

47 We would like to thank Tea Sušanj Protić and Laris Borić for the discussion.
} 


\section{DISCUSSION}

The results from the integrated prospection of Osor are very encouraging. Nevertheless, there are topics of an interpretative nature that still need to be addressed. Current GPR results indicate that all of the area within the city wall was probably used for buildings from at least the Roman development phase. In comparison, our 1.8 ha of geophysical measurements have not even covered $1 / 4$ of the ancient city. The results presented here can therefore be only seen as a first step in the attempt to understand the structure of antique Osor.

\section{City topography}

To begin with, the city wall is not completely preserved today. Some parts are conserved under the later Venetian wall, while other parts have completely disappeared. On the northern side of the city, strong winds and waves have certainly played a major role in its complete erosion (fig. 17). The north-east and the eastern sections have probably been subject to stone exploitation - the Mediterranean tradition of reusing stone material continues up to this day in Osor. Some parts of the city wall have been repeatedly rebuilt over the centuries and have partly changed their spatial position, which is especially apparent in the northern and eastern sections. The exact phases of construction are not understood in detail due to a lack of preserved remains, resulting in different reconstructions of the settlement areas and the course of the surrounding city wall ${ }^{48}$. Archaeological excavations during the 1970 ies $^{49}$ provided new evidence about its chronology, however the excavated areas are simply too small to adequately address the complex situation. Therefore, further archaeological work is necessary before a comprehensive reconstruction of the city wall can be made. However, the topographical data does clearly indicate the size and form of the settlement area (fig. 18). Therefore, from this we can get an idea of the former extent of the city.

The modern road leading from Cres into Osor is situated west of the city on a thin elevation crossing the humid valley (fig. 18). At present it is not possible to say whether this elevation has occurred naturally or artificially. A natural entrance to the city, however, is located at another place on the northeastern edge of the city facing the bay of Bijar ${ }^{50}$. Also old maps show a similar topographical setting (fig. 18). Together with the DTM they make it clear to which degree the topography north-east of the city has changed during the time.

As already mentioned in the chapter Case Study area, an unresolved issue is the question whether the area of ancient Osor was a peninsula (as it is today) or whether it could have been a small island. If the natural entrance was located in the northeastern edge of the city, this old debate becomes actual again. At present, the first geoarchaeological results seem to bite against a natural bay or a harbor between the bay of Bijar and the bay of Jaz. During October 2015 two sediment cores were taken in the Bijar bay, using a Cobra vibracoring system. Both cores started less than $25 \mathrm{~cm}$ above the sea-level at that day. The first core reached only $0.7 \mathrm{~m}$, while the second one reached $4.5 \mathrm{~m}$ depth. Generally, the grain size was very fine-grained and decreased from sandy clay in the uppermost $150 \mathrm{~cm}$ with common angular limestone clasts, to highly plastic clays with only a few limestone clasts in the lower part. Virtually no artifacts were found, except very few, small brick/ceramic fragments in the uppermost $80 \mathrm{~cm}$. Given the lower sea level at Roman times

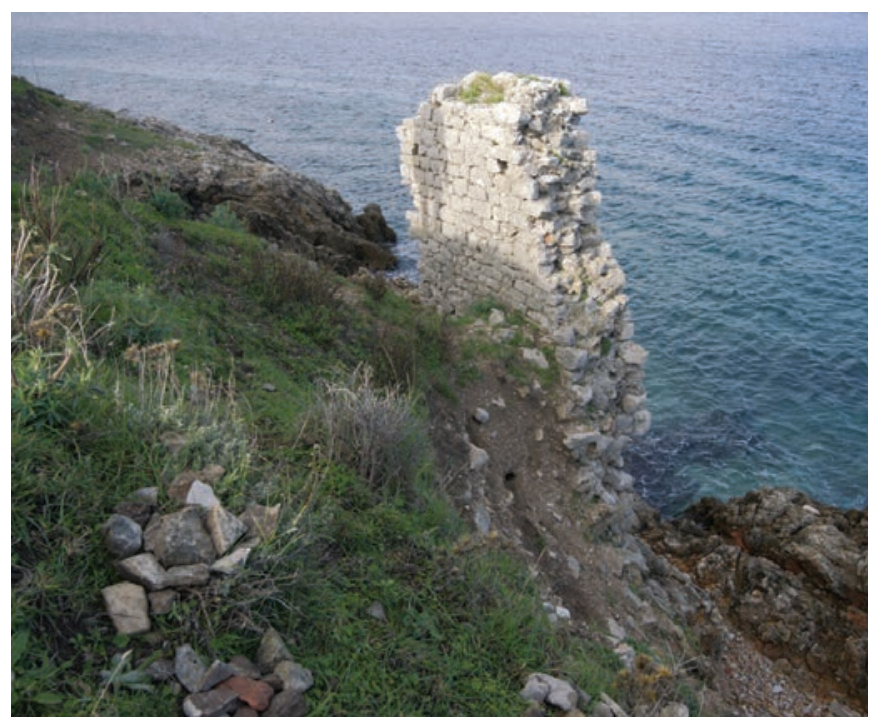

Fig. 17: The northern part of the city wall is almost completely eroded due to the strong winds and waves. CMichael Doneus

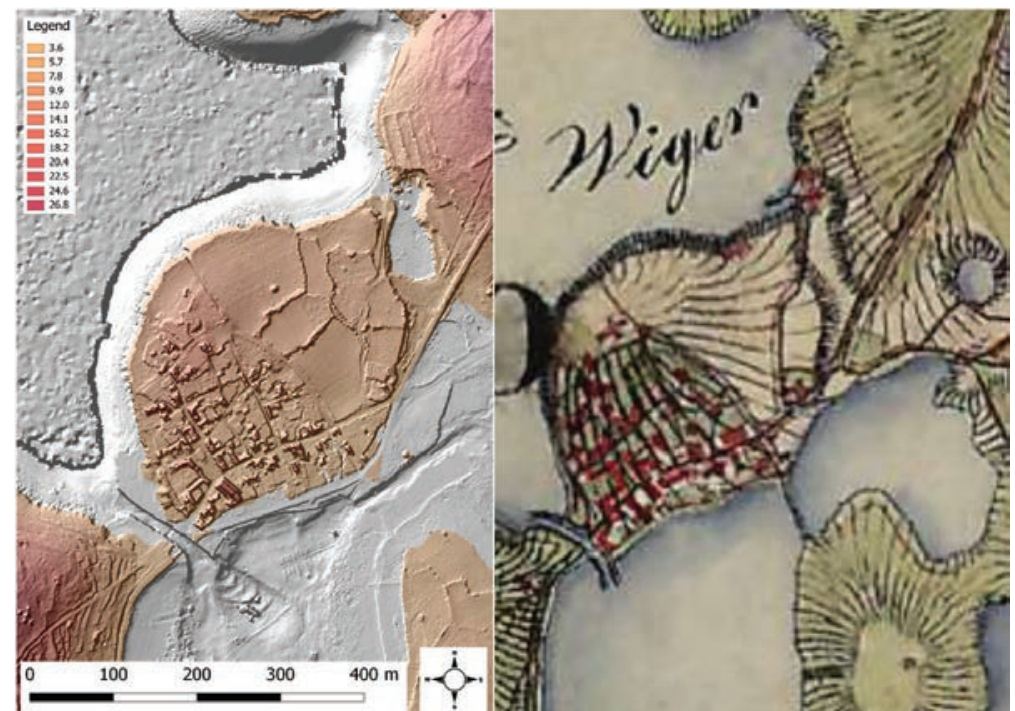

Fig. 18. Left: DTM indicating the city area with a natural entrance to the city in the northeast. (CLBI ArchPro. Right: A similar topographical situation is noted on the Second Military Survey map (coastal region mapped in 1821-1824) ${ }^{51}$.

\footnotetext{
${ }^{48}$ See for example: A. MOHOROVIČIĆ, « Pregled i analiza novootkrivenih objekata historijske arhitekture na području grada Osora », Bulletin Instituta za likovne umjetnosti JAZU, 1-2, Zagreb, 1953, p. 11. A. FABER, « Osor-Apsorus iz aspekta antickog pomorstva », Diadora, 9, Zadar, 1980, fig. 3.

${ }^{49}$ See the research history in the chapter Case study. The reconstruction of the late antique city wall as suggested by A. Faber could not be confirmed with the GPR data: A. FABER, « Osor-Apsorus iz aspekta antickog pomorstva », Diadora, 9, Zadar, 1980, fig. 4.

${ }^{50}$ A similar consideration had already A. Faber, noticing that one of the city entrances at some point of time was to be expected there A. FABER, « Počeci urbanizacije na otocima sjevernog Jadrana », Izdanja $H A D$, 7, Zagreb, 1982, prilog 1.

${ }^{51}$ Historical maps of the Habsburg Empire can be found on www.mapire.eu. See also E. BISZAK, H. KULOVITS, S. BISZAK, G. TIMÁR, G. MOLNÁR, B. SZÉKELY, A. JANKÓ, I. KENYERES, « Cartographic heritage of the Habsburg Empire on the web: the MAPIRE initiative ", in $9^{\text {th }}$ International Workshop on Digital Approaches to Cartographic Heritage Budapest, 4-5 September 2014, At 26-31, Volume: 9. DOI: 10.13140/2.1.4331.4561.
} 
it seems, however, unlikely that the fine sediments can be interpreted as a silted Roman harbor. At the moment, a more likely interpretation of the area might be a silted up karstic sinkhole. Further analysis and especially radiocarbon dating of the charcoal is going on ${ }^{52}$.

\section{City layout}

Much of what we think today about the Roman Osor, goes back to the $1950 i e s$ and the work of Andre Mohorovičić. Since his research focused mainly on „historical urbanistic and architectural objects" 53 , no Iron Age roots of the city were examined or taken into consideration when it comes to the development of the Roman city. Since there have been no systematic investigations of the pre-Roman settlements (Bronze and Iron Age), the extent of any influence of the Iron Age city layout on the subsequent Roman road system remains uncertain.

A reconstruction of the streets within the city also raises the question of the main roads (cardo and decumanus) and the forum in the Roman times. This question was also important in the earliest work of Mohorovičić. In his research, Mohorovičić was trying to reconstruct the main roads from a „theoretical connection (between) the well-known west entrance and the presumed east entrance into the city". A subsequent excavation $(1.5 \times 1.5 \mathrm{~m})$ near this imaginary line resulted in findings of a mosaic, which led the author to assume that this was an „important“ object, possibly at the crossroads of cardo and decumanus ${ }^{54}$. The location of the forum is assumed in the south-west part of the town, beneath today's main square, based on the results from small scale excavations ${ }^{55}$.

The location of the forum on the outskirts of the city is not an unusual solution ${ }^{5}$, but the sources currently available can - in our opinion - neither confirm nor disprove the theories about the street raster or the location of any public buildings. Single rescue excavations conducted in the last decades in Osor are simply too small in scope to allow an understanding of building function. Osor, as an administrative and cultural center ${ }^{57}$, certainly had numerous public buildings, as well as some luxurious residential buildings and areas, making it difficult to recognize the „important“ buildings only by means of single architectural parts (mosaics etc. $)^{58}$. Published references, which indicate localisation of other public buildings in the city or outside (theater, horrea, therme) are based on even thinner archaeological evidence ${ }^{59}$. Even the systematic excavations in the area of monastery of Saint Peter, which was built on top of the antique city, demonstrate how difficult it is to understand the function of individual buildings ${ }^{60}$.

For the same reason, a functional interpretation of the individual building complexes - at the current level of interpretation - would have little substance. Although one gets a three-dimensional image of the sub-surface, its interpretation is complicated. While at first glance one tends to see a coherent layout of roads and buildings, one must be aware that in the case of a settlement activity lasting for several centuries, a complex building history is to be expected with re-building, destruction, stone extraction, levelling, as well as complete reconstruction of single areas of the city.

Getting a three-dimensional image of the sub-surface structures can, however, reveal different construction phases. One example of such a documented overlap seems to be worth mentioning (fig. 14). Within parcel 996, the series of time slices of the radargram reveal disturbances and overlaps with the course of the assumed Roman roads. The small church mentioned before is partly located above an older road. In the north-west area of the parcel a courtyard is visible ( $13 \times 13.5 \mathrm{~m}$ and $6.2 \times 7.8 \mathrm{~m}$ ) containing a well or similar water facility with a diameter of about $1.3 \mathrm{~m}$ and a depth up to about $2.5 \mathrm{~m}$. The inner courtyard is surrounded by rooms of different sizes, which are partly overlapping. They are indicating at least two different building complexes that have a slightly different orientation. On the northern side, there is a room or an annex $(4.3 \times 6.6 \mathrm{~m})$, built from very massive walls, reaching a depth of more than $2 \mathrm{~m}$.

Apart from the courtyard - which can be clearly recognized in the GPR data - an understanding of the function of the adjoining rooms is at the current level of research difficult ${ }^{61}$. In addition, a courtyard is not only confined to Roman architecture, but can also be found in building complexes of younger times. For Osor we can also presume that some of the buildings detected by the GPR originate either from the Byzantine time or from the Middle Ages. In this context a certain similarity in the arrangement of rooms around an inner courtyard (and perhaps a tower in the north-east of

\footnotetext{
${ }^{52}$ The article about the geoarchaeological investigations is in preparation.

${ }^{53} \mathrm{~A}$. MOHOROVIČIĆ, « Pregled i analiza novootkrivenih objekata historijske arhitekture na području grada Osora », Bulletin Instituta za likovne umjetnosti JAZU, 1-2, Zagreb, 1953, p. 10.

${ }^{54}$ A. MOHOROVIČIĆ, « Pregled i analiza novootkrivenih objekata historijske arhitekture na području grada Osora », Bulletin Instituta za likovne umjetnosti JAZU, 1-2, Zagreb, 1953, p. 11.

55 J. ĆUS-RUKONIĆ, « Izvori za arheologiju Cresa i Lošinja », Otočki ljetopis Cres-Lošinj, 5, Mali Lošinj, 1984, p. 234.

$5^{56}$ On the development of the forum location in Roman cities see M. SUIĆ, Antički grad na istočnom Jadranu, Zagreb, 1976, p. $125 \mathrm{ff}$.

${ }^{57}$ A. STARAC, Rimsko vladanje u histriji i liburniji II. Društveno i pravno uređenje prema literarnoj, natpisnoj i arheološkoj građi, Monografije i katalozi Arheološkog muzeja Istre, 10/II, Pula, 2000, p. 79 ff.

${ }^{58}$ J. ĆUS-RUKONIĆ, «Imperial Cult - New Discoveries at the Roman Forum on the Island of Cres », Carski kult na istočnom Jadranu, Materijali, 9, 1997, p. 69-70. The excavation in the area of today's museum on a city main square showed traces of Roman building phase, however no confirmation of the forum or a public building (Manuscript: Osor. Izvješće o zaštitnom arheološkom istraživanju u dijelu prizemlja loggie zgrade arheološke zbirke Osor, siječanj/veljača 2006).

${ }^{59}$ E. IMAMOVIĆ, « Antička naselja na otočinoj skupini Cres - Lošinj », Otočki ljetopis Cres-Lošinj, 2, Mali Lošinj, 1975, p. 218 f. J. ĆUS-RUKONIĆ, ed., Utvrde cresko-lošinjskog otočja od pretpovijesti do današnjih dana, Katalog izložbe. Mali Lošinj, 2013, p. 12.

${ }^{60}$ S. BULLY, M. JURKOVIĆ, M. ČAUŠEVIĆ-BULLY, I. MARIĆ, « Benediktinska opatija Sv. Petra u Osoru - arheološka istraživanja 2006.-2013 », Izdanja $H A D$, 30, Zagreb, 2015, p. 108.

${ }^{61}$ For Roman times see e.g. functional changes of buildings in Salona: T. TURKOVIĆ, N. MARAKOVIĆ, «»Velike salonitanske terme« - od antičke kuće do biskupskih kupelji », Radovi Instituta za povijest umjetnosti, 38, Zagreb, 2014, p. 25-40.
} 
the complex) with a ground floor of a Christian monastery can be noticed ${ }^{62}$. This would be in accordance with historic sources, which tell that the monastery of Saint Peter is one of two Benedictine monasteries established in the $11^{\text {th }}$ century in $\mathrm{Osor}^{63}$. While one of them has been identified by the Croatian-French team next to the church of Saint Peter ${ }^{64}$, the second one, a nunnery, has not been found yet and is known only through written sources ${ }^{65}$. It would be therefore tempting to hypothesize the younger building complex as the missing nunnery. However, the main feature of a monastery, namely a church, is missing in the ground plan of the radargram. Therefore, only further research, possibly including a small-scale excavation, would be able to clarify the chronology and the function(s) of these architectural remains.

\section{CONCLUSION}

The Mediterranean landscape of Osor is a complex research environment consisting of interrelated terrestrial and aquatic components. Therefore, an integrated approach for documentation, investigation and interpretation of archaeological sites is needed. These areas have, until now, always been studied separately, because of obvious difficulties involved in combining submarine and terrestrial archaeology. The research presented in this paper has shown that this gap can now be closed by advances in archaeological prospection that allow the combined study of coastal sites above and below the surface of the water using a combination of ALS and ALB data capture. In the long term, this will not just improve our understanding of archaeological landscapes but also help to develop improved approaches for documentation and protection of both marine and terrestrial cultural heritage.

Although the interpretation offered in this paper can only give a rough overview and therefore has to be regarded as provisional, it provides deeper insights into old questions about the ancient and historic city of Osor. The results from our study have shown that combined methods of ALS and GPR have successfully revealed significant previously undocumented archaeological and environmental remains. These include the topography as well as diverse archaeological remains hidden by the vegetation, seawater and soil.

These new results have answered some questions about ancient and historic Osor, and have also raised many new ones. This should stimulate further archaeological investigations in the region, since an archaeological interpretation based on prospection data is always only provisional.
With regard to ALS, further work on visibility of archaeological structures is necessary. Latest, drone-based devices seem to be a promising solution to penetrate even very dense, evergreen vegetation. This could result in more detailed terrain models, which would be better to interpret. In geophysics, the repeated use of different methods, including GPR and magnetometry, would be needed to achieve the best possible results. Additionally, there is also a need for an interdisciplinary approach that would make an integrated interpretation of available archaeological and geoarchaeological sources possible, including small-scale, targeted excavations, which would help to answer chronological questions. Nevertheless, the work presented in this paper represents an integrated foundation that provides us with a holistic view of archaeological heritage in Osor at numerous levels, and a deeper understanding of the nature of past human activity in a complex Mediterranean context.

\section{ACKNOWLEDGEMENTS}

The flight and the geophysical measurements were funded by RGZM Mainz during the project "Harbors and landing places on the Balkan coasts of Byzantine empire (4.-12. century). Technology and monuments, economy and communication." GPR measurements were carried out within the scope of the LBI ArchPro case study by a following team: Manuel Gabler, Matthias Kucera, Hannes Schiel, Viktor Jansa, Michael Doneus and Nives Doneus.

The authors wish to express their thankfulness to Morana Čaušević-Bully and Sébastien Bully for many valuable hints through the last years, Miljenko Jurković for the discussion on a city layout and Aleksandra Faber for visiting Osor and a discussion in 2015.

The Ludwig Boltzmann Institute for Archaeological Prospection and Virtual Archaeology (archpro.lbg.ac.at) is based on an international cooperation of the Ludwig Boltzmann Gesellschaft (A), Amt der Niederösterreichischen Landesregierung (A), University of Vienna (A), Vienna University of Technology (A), ZAMG - Central Institute for Meteorology and Geodynamics (A), Airborne Technologies (A), 7reasons (A), ÖAW - Austrian Academy of Sciences (A), ÖAI - Austrian Archaeological Institute (A), RGZM Mainz - Römisch-Germanisches Zentralmuseum Mainz (D), University of Birmingham (GB), Statens Historiska Museer (S), NIKU - Norwegian Institute for Cultural Heritage (N) and Vestfold fylkeskommune - Kulturarv (N).

\footnotetext{
62 S. SEKULIĆ-GVOZDANOVIĆ, Utvrđeni samostani na tlu Hrvatske, Zagreb, 2007, p. $115 \mathrm{ff}$.

${ }_{3}^{6}$ M. JURKOVIĆ, « Benediktinci na sjevernom Jadranu », Opatijske crkvene obljetnice, Zbornik radova sa znanstvenog skupa održanog u Opatiji 17. i 18. studenoga 2006. godine, Opatija, 2008, p. 7-30.

${ }^{64}$ S. BULLY, M. JURKOVIĆ, M. ČAUŠEVIĆ-BULLY, I. MARIĆ, (2007): L'église du monastère Saint-Pierre d'Osor (ile de Cres). Première campagne d’étude, Hortus artium medievalium, 13 (2), Zagreb, 2007, p. 441-456. DOI: 10.1484/J.HAM.2.305429.

${ }_{5}^{65}$ I. OSTOJIĆ, Benediktinci u Hrvatskoj I ostalim našim krajevima, Sv. II Benediktinci u Dalmaciji, Split, 1964, p. 196 ff.
} 